\title{
Hydraulic Effects of Recharging the Magothy Aquifer, Bay Park, New York, With Tertiary-Treated Sewage
}

GEOLOGICAL SURVEY PROFESSIONAL PAPER 751-F

Prepared in cooperation

with Nassau County

Department of Public Works 



\section{Hydraulic Effects of Recharging the Magothy Aquifer, Bay Park, New York, With Tertiary-Treated Sewage}

By JOHN VECCHIOLI, HENRY F. H. KU, and DENNIS J. SULAM

DEEP-WELL ARTIFICIAL-RECHARGE EXPERIMENTS A T B Y PARK, LONG ISLA D, NEW YORK

GEOLOGICAL SURVEY PROFESIONAL PAPER $751-$ F

Prepared in cooperation

with Nassau County

Department of Public Works

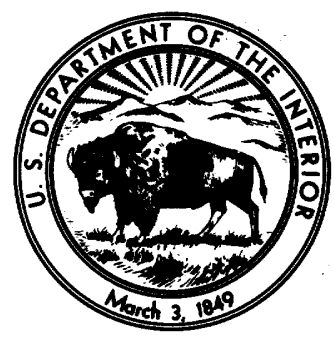




\title{
UNITED STATES DEPARTMENT OF THE INTERIOR
}

\author{
CECIL D. ANDRUS, Secretary
}

GEOLOGICAL SURVEY

H. William Menard, Director

\section{Library of Congress Cataloging in Publication Data}

Vecchioli, John.

Hydraulic effects of recharging the Magothy aquifer, Bay Park, New York, with tertiary-treated sewage. (Deep-well artificial-recharge experiments at Bay Park, Long Island, New York) (Geological Survey professional paper ; 751-F)

Supt. of Docs. no.: I 19.16:751-F

Bibliography: p.

1. Water, Underground-New York (State)-Bay Park-Artificial recharge. 2. Sewage disposal in the ground-New York (State)-Bay Park. I. Ku, Henry F. H., joint author. II. Sulam, Dennis J., joint author. III. Nassau Co., N. Y. Dept. of Public Works. IV. Title. V. Series. VI. Series: United States. Geological Survey. Professional paper ; 751-F.

$\begin{array}{lll}\text { TD765.V38 } & 628^{\prime} .36 & 78-27041\end{array}$

For sale by the Superintendent of Documents, U.S. Government Printing Office

Washington, D.C. 20402

Stock Number 024-001-03291-1 


\section{CONTENTS}

Conversion factors and abbreviations

Abstract

Introduction

Purpose and scope

Water-reclamation and recharge facilities -...--

Geohydrology of recharge site

Previous work

Acknowledgments _........

Nature of testing

Pumping tests

Injection experiments with public-supply water-Injection experiments with reclaimed water -..-

Well-redevelopment experiments

Effect of injection on aquifer head

Theoretical head buildup

Observed head buildup

\begin{tabular}{r|r} 
Page & IV \\
F1 & Injection-well performance \\
1 & Changes in specific capacity \\
1 & Effect of temperature on specific capacity \\
2 & Well clogging \\
2 & Mechanical clogging \\
3 & Biological clogging \\
3 & Chemical clogging \\
4 & Flowmeter surveys \\
4 & Redevelopment of recharge well \\
4 & Pumping and surging \\
5 & Acid treatment \\
5 & Bactericide treatment \\
6 & Resting \\
6 & Summary -
\end{tabular}

Page

F7

7

10

11

11

13

14

14

16

16

17

18

19

19

20

\section{ILLUSTRATIONS}

Figure 1. Map showing location of artificial-recharge site, Bay Park, New York

2. Graph showing time drawdown curves for observation well $20 \mathrm{ft}$ from injection well from measurements taken during pumping tests before any injection and after final injection test

3. Graph showing time drawdown curves for injection well from measurements taken during pumping tests before any injection and after final injection test

4. Curves showing relation between distance from injection well and drawdown or head buildup after 1 day, at pumping rate of $350 \mathrm{gal} / \mathrm{min}$. (Based on water levels in observation wells 20, 100, and 200 ft from injection well.)

5. Graph showing equilibrium head buildup at selected depths and distances from injection well. (Based on water levels in observation wells 20,100 , and $200 \mathrm{ft}$ from injection well and at injection rate of $350 \mathrm{gal} / \mathrm{min}$.)

6. Hydrographs of selected observation wells during injection test RW13, October 24, 1972, to May 11, 1973

7. Graph showing comparison of head buildup and turbidity during test RW7, April 14 to May 17, 1970

8. Diagram showing head buildup in injection well during test RW9, April 27 to May 7, 1971, and turbidity of water injected

9. Graph showing relationship between suspended solids in injected water and rate of head buildup in injection well

10. Diagram showing depth distribution of flow through well screen during (a) initial flowmeter survey before any injection, (b) pumping before test RW4, and (c) injection in test RW4 


\section{TABLES}

TABLE 1. Data on injection tests at Bay Park, N.Y., 1968-1972

3. Statistical comparison of drawdowns at observation wells after 1 day of pumping with head buildups after 1 day of injection

4. Clogging rates in test RW13, October 24,1972 , to May 11,1973

5. Unadjusted and adjusted end-of-test specific capacities determined in

6. Turbidity of injected water in tests RW3-RW13 (except RW6) and corresponding decrease in specific capacity --

7. Aluminum, iron, and phosphate concentrations and $\mathrm{pH}$ of liquid pumped after acid treatment of injection well after test RW7

8. Redevelopment data, test RW13, October 24,1972 , to May 11,1973

\section{CONVERSION FACTORS AND ABBREVIATIONS}

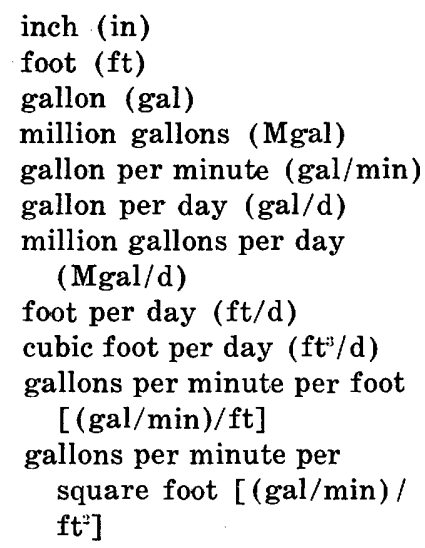

$=25.4$

$=0.305$

$=3.785$

$=3.785 \times 10^{3}$

$=3.785$

$=3.785$

$=4.381 \times 10^{-2}$

$=0.305$

$=2.832 \times 10^{-2}$

$=2.07 \times 10^{-1}$

$=40.677$
Metric units

millimeters $(\mathrm{mm})$

meters $(\mathrm{m})$

liters $(\mathrm{L})$

liters $(\mathrm{L})$

liters per minute $(\mathrm{L} / \mathrm{min})$

liters per day $(\mathrm{L} / \mathrm{d})$

cubic meters per second $\left(\mathrm{m}^{3} / \mathrm{s}\right)$

meter per day $(\mathrm{m} / \mathrm{d})$

cubic meters per day $\left(\mathrm{m}^{3} / \mathrm{d}\right)$

liters per second per meter $[(\mathrm{L} / \mathrm{s}) / \mathrm{m}]$

liters per minute per square meter $\left[(\mathrm{L} / \mathrm{min}) / \mathrm{m}^{2}\right]$ 


\title{
HYDRAULIC EFFECTS OF RECHARGING THE MAGOTHY AQUIFER, BAY PARK, NEW YORK, WITH TERTIARY-TREATED SEWAGE
}

\author{
By John Vecchioli, Henry F. H. Ku, and Dennis J. Sulam
}

\begin{abstract}
From 1968 to 1973 , water from public supply and water reclaimed from sewage were used in a series of 19 artificialrecharge experiments at Bay Park, N.Y. Recharge to the Magothy aquifer was through a fiberglass-cased well with a 16-inch-diameter stainless-steel screen set from 418 to 480 feet below land surface. Tests ranged from 2 to 33 days, except for the final test, in which water was injected intermittently over a 6 -month period. During the 6-month test, a total of 42 million gallons of water was injected. In some tests, selected treatments were applied to the injectant to evaluate their effects on well clogging and to determine whether they caused geochemical reactions within the aquifer. After each test, the injected water was pumped out of the aquifer.

The recharge well and contiguous parts of the aquifer developed varying degrees of clogging, which resulted in excessive head buildup in the recharge well. Maximum reduction in specific capacity from 23.5 to 2.5 gallons per minute per foot occurred during injection of 14 million gallons of reclaimed water.

Clogging of the recharge well was caused primarily by suspended-solids content (turbidity) of the injected water. Concentrations above 1 milligram per liter as silica caused disproportionately higher rates of clogging than those below 1 milligram per liter. Microbial growth was an insignificant factor in clogging as long as a total residual chlorine level of about 2 milligrams per liter was maintained.

Specific capacity of the recharge well diminished gradually during injection but was partly restored by pumping and surging the well. Pumping rate was commonly 400 to 500 gallons per minute. Dosing the well with hydrochloric acid aided in removal of clogging material that could not be dislodged by pumping alone. Dosing with solutions of sodium hypochlorite and a bactericidal ammonium compound resulted in some improvement in specific capacity. Biodegradation of the clogging materials occurred when the well was idle after injection; redevelopment by pumping and surging was more successful after idle periods of several weeks.
\end{abstract}

\section{INTRODUCTION}

Growth in the population of Nassau County, a suburb of New York City, has been accompanied by increased withdrawals of ground water, which, in 1974 , was the only source of public-supply water. Net withdrawals from the ground-water system have resulted in declining ground-water levels and decreased streamflow (Franke, 1968; Garber and Sulam, 1976) and in local landward movement of salty ground water (Lusczynski and Swarzenski, 1966; Cohen and Kimmel, 1970). A continued increase in net withdrawals is expected as population, per capita water use, and percentage of population served by sewers increase. These growth factors indicate a watersupply deficit of between 71.1 and $91.1 \mathrm{Mgal} / \mathrm{d}$ by 1990 (Temporary State Commission on Water Supply Needs of Southeastern New York, 1972, p. 142-144).

One of several alternatives under consideration by Nassau County to meet the anticipated water-supply deficit is reclamation of water from sewage and injection of the reclaimed water into the ground-water reservoir (Peters and Rose, 1968). From 1968 to 1973, the Nassau County Department of Public Works operated a pilot advanced waste-treatment plant at Bay Park, N.Y., near the south shore of Nassau County (fig. 1). Reclaimed water from this plant was used in a series of deep-well artificial-recharge experiments by the U.S. Geological Survey in cooperation with the Nassau County Department of Public Works. These tests were intended to provide some of the scientific and engineering data needed to evaluate the degree, causes, and remedies for well clogging that results from injection of reclaimed water and the geochemical compatibility of the reclaimed water with the aquifer.

\section{PURPOSE AND SCOPE}

This report is the sixth and last chapter in U.S. Geological Survey Professional Paper 751, "DeepWell Artificial-Recharge Experiments at Bay Park, 


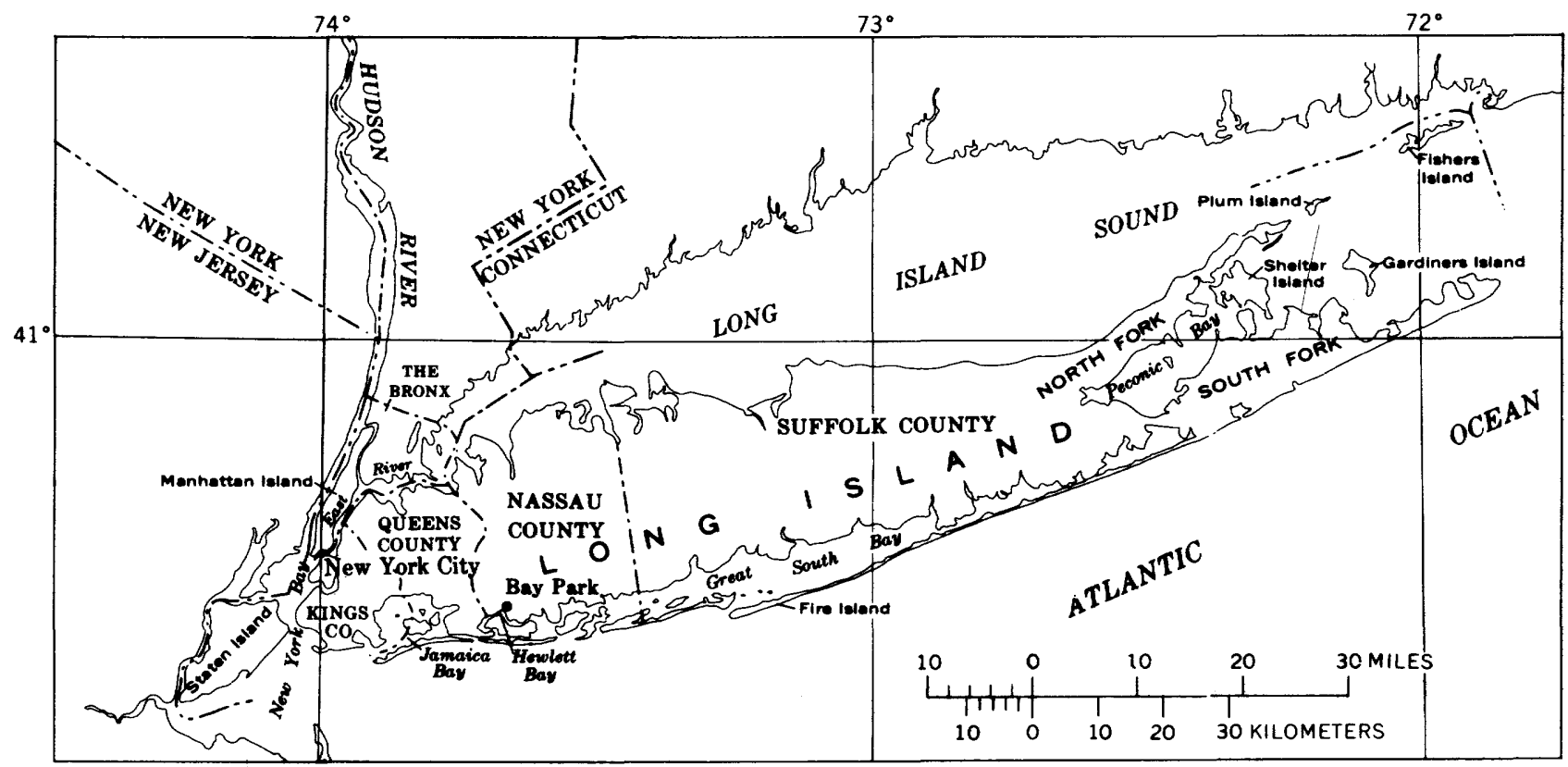

FigURe 1.-Location of artificial-recharge site, Bay Park, New York. (From Vecchioli and others, 1974, p. 2.)

Long Island, New York." The report documents the testing that was done, evaluates the hydraulic response of the aquifer to the recharge, and describes the performance of the recharge well and the factors that affected performance. In this report, emphasis is on the hydraulic aspects of the testing; geochemical and microbiological aspects are covered in earlier chapters. (See section "Previous Work.")

\section{WATER-RECLAMATION AND RECHARGE FACILITIES}

Reclaimed water for recharge was obtained by tertiary-stage treatment (Peters and Rose, 1968; Peters, 1968; Vecchioli, Oliva, Ragone, and $\mathrm{Ku}$, 1975 ) of about $0.6 \mathrm{Mgal} / \mathrm{d}$ of the effluent from an activated-sludge type $60-\mathrm{Mgal} / \mathrm{d}$ sewage-treatment plant. This treatment consisted generally of coagulation and sedimentation, primary filtration through a dual-media sand-anthracite filter followed by secondary filtration through one to four activated carbon columns, and finally chlorination. Additional treatment that was applied at times at the recharge facility included degasification, $\mathrm{pH}$ adjustment, and dechlorination.

Major components of the recharge facility included (1) a 50,000-gallon storage tank into which either public-supply water or reclaimed water was delivered, (2) a vacuum-operated degasifier, (3) injection and redevelopment pumps with automatic flow controls, (4) an injection well consisting of an 18-inch-diameter fiberglass casing above a 16-inchdiameter stainless-steel well screen set at 418 to 480 feet below land surface, (5) 18 observation wells, ranging from 20 feet to 200 feet from the injection well, some of which were equipped with water-level recording equipment, and (6) equipment for monitoring several chemical and physical characteristics of the water.

\section{GEOHYDROLOGY OF RECHARGE SITE}

The recharge site is in the Atlantic Coastal Plain and is underlain by 1,250 feet of unconsolidated deposits of Pleistocene and Late Cretaceous age, which, in turn, overlie crystalline bedrock of Precambrian age. The recharge well is screened within the lower part of the Magothy aquifer in the Matawan GroupMagothy Formation undifferentiated of Late Cretaceous age, at a depth of 418 to 480 feet below land surface. The screened interval (injection zone or receiving zone) is mostly a stratified fine to medium quartz sand sandwiched between and semiconfined by beds of the Magothy Formation of lesser hydraulic conductivity. At Bay Park, the Magothy aquifer is confined by the underlying clay member of the Raritan Formation, also of Late Cretaceous age, but above, it is virtually unconfined, owing to the generally coarse-grained character of the overlying Pleistocene deposits. Lateral hydraulic conductivity of the stratified injection zone averages 940 ( $\mathrm{gal} /$ d) $/ \mathrm{ft}^{2}$ or $126 \mathrm{ft} / \mathrm{d}$, but flowmeter surveys indicated considerable variation within this interval. The hydraulic characteristics of the aquifer system were determined by standard aquifer-test methods; the 
results were later verified by electric analog-model studies.

\section{PREVIOUS WORK}

The geology and ground-water conditions in southern Nassau and southeastern Queens Counties, including the Bay Park area, were discussed by Perlmutter and Geragthy (1963). Lusczynski and Swarzenski (1966) gave a detailed description of the hydrologic environment in southeast Nassau County. General discussions of more recent regional hydrologic conditions were given by Cohen, Franke, and Foxworthy (1968). The geohydrology of the Bay Park site was described in brief by Perlmutter, Pearson, and Bennett (1968) and in detail by Vecchioli, Bennett, Pearson, and Cerrillo (1974).

Scope and objectives of the Bay Park wastewaterreclamation and artificial-recharge project have been described by Cohen and Durfor (1967) and by Peters and Rose (1968). These reports also contain general descriptions of the facilities. A detailed description of the recharge well was given by Cohen and Durfor (1967). Koch, Giaimo, and Sulam (1973) described in detail the design and operation of all recharge facilities, including the injection well.

Many progress reports have dealt with all or most aspects of the project in varying detail. Peters (1968) commented on the overall project and included some discussion of early operations of the treatment and injection plants. Vecchioli and $\mathrm{Ku}$ (1972) presented preliminary results of early injection experiments. These early results were later updated and summarized by Vecchioli (1972). Principal conclusions drawn from all the tests made were discussed in brief by Vecchioli, Oliva, Ragone, and $\mathrm{Ku}$ (1975). Significant features of the longest recharge test (41.7 Mgal over a 6-month period) were reported by Sulam (1973).

Reports dealing specifically with geochemical aspects of the recharge experiment include Vecchioli and Giaimo (1972) on potential corrosion of metals; Faust and Vecchioli (1974) on several problems; Ragone, Vecchioli, and $\mathrm{Ku}$ (1973) and Ragone, Ku, and Vecchioli (1975) on dissolution of iron from the aquifer; Ragone and Vecchioli (1975) on pyrite dissolution and ion-exchange reactions; and $\mathrm{Ku}$, Vecchioli, and Ragone (1975) on movement of sewage-related substances through the aquifer. Ragone (1977) presented a comprehensive discussion of all geochemical problems studied.

Bacterial growth around the injection well and the significance thereof was described by Vecchioli (1970) and Ehrlich, Ehlke, and Vecchioli (1972 and
1973). Movement of bacteria through the aquifer along with the injected water was discussed by Vecchioli, Ehrlich, and Ehlke (1972). Additional microbiological aspects were reported in detail by Ehrlich, Ku, Vecchioli, and Ehlke (1979).

\section{ACKNOWLEDGMENTS}

Individuals who had a major role in the design and construction of the injection facilities include John H. Peters, former Commissioner of the Nassau County Department of Public Works; John L. Rose, formerly of Burns and Roe, Inc.; Philip Cohen and Bruce L. Foxworthy, U.S. Geological Survey; and Charles N. Durfor, formerly with the Geological Survey. Particular recognition is given Messrs. Cohen and Durfor, whose efforts early in the project made possible the detailed testing of the hydraulics and hydrochemistry of the aquifer system.

The installation and early testing of the wells were done under the joint direction of Messrs. Cohen and Durfor. Most of the credit for the design of the operating controls and monitoring instrumentation of the injection facilities belongs to Mr. Durfor. In preparation for the injection of reclaimed water, Gordon D. Bennett of the Geological Survey directed extensive hydraulic testing of the injection facilities, the injection well, and the aquifer; many of the test procedures developed by him were followed with little modification throughout the project. G. D. Bennett and F. J. Pearson, Jr., directed the early recharge tests, where public-supply water was used; some of the data from those tests are included in this report.

The authors are especially grateful to former Commissioner John H. Peters and Deputy Commissioner James S. Gillen, Nassau County Department of Public Works, for making available the physical and human resources of the Department throughout the project. Particular thanks are given also to Francis J. Flood, former Superintendent of Operations and Maintenance; James A. Oliva, Sanitary Engineer; and to many others in the Department for coordinating water-treatment operations with the injection experiments, for providing assistance in modifying the injection equipment, and for helping with various measurements. Louis S. Guaracini of the Department of Public Works provided numerous chemical analyses throughout the project.

Advice and assistance on chemical aspects of well clogging were provided by Samuel D. Faust, Department of Environmental Science, Rutgers University, and by Stephen E. Ragone, Geological Survey. Garry G. Ehrlich and Theodore A. Ehlke, Geological Sur- 
vey, gave advice and assistance on microbiological aspects of deep-well injection.

Several personnel of the Geological Survey assisted in making test measurements and in reducing and compiling data. Particular recognition in this respect is given Anthony $\mathrm{A}$. Giaimo and Lillian $\mathrm{B}$. Machlin for their assistance throughout the project. The authors are grateful to all who assisted.

\section{NATURE OF TESTING}

\section{PUMPING TESTS}

Pumping tests were made on the injection well and some of the observation wells before the start of the injection experiments to determine initial hydraulic characteristics of the injection well and the aquifer zone tapped by the well (Vecchioli and others, 1974). Numerous other pumping tests, ranging from several hours to several days in duration, were made on the injection well from time to time throughout the testing period. Changes in hydraulic characteristics resulting from injection were determined by comparison of early pumping-test results with later ones.

The pumping rate in most pumping tests of the injection well was approximately $400 \mathrm{gal} / \mathrm{min}$. The rate was determined with a magnetic flowmeter. Volumetric calibrations of flow were made in nearly all tests.

Water levels in the injection well and selected observation wells were measured in all tests. These measurements were obtained with a combination of automatic float-activated water-level recorders, electric water-level indicators, and chalked steel tapes.

Flowmeter surveys were run in the screened part of the injection well during the initial pumping tests (Vecchioli and others, 1974) and in some of the pumping tests that followed early injection tests. Percentage of total discharge contributed by each 5 -foot interval of well screen was measured by a 3inch Au-type current meter.

\section{INJECTION EXPERIMENTS WITH PUBLIC-SUPPLY WATER}

Before reclaimed water was injected, four injection tests with water from the local public-supply distribution system were completed. These tests were done to identify any major problems associated with the injection operation and to evaluate procedures of operation and data collection. The period of injection in these tests was from 2 to 3 days. The rate of injection was either 200 or $400 \mathrm{gal} / \mathrm{min}$,
TABLE 1.--Data on injection tests at Bay Park, N.Y., 1968-1972

\begin{tabular}{|c|c|c|c|c|}
\hline Test 1 & $\begin{array}{c}\text { Approxi- } \\
\text { mate } \\
\text { length } \\
\text { of } \\
\text { time } \\
\text { (days) }\end{array}$ & $\begin{array}{l}\text { Injec- } \\
\text { tion } \\
\text { rate } \\
\text { (gal/ } \\
\text { min) }\end{array}$ & $\begin{array}{l}\text { Gallons } \\
\text { injected } \\
\text { (thou- } \\
\text { sands) }\end{array}$ & $\begin{array}{l}\text { Special } \\
\text { treatment } \\
\text { of water }\end{array}$ \\
\hline \multicolumn{5}{|c|}{ Public-Supply Water } \\
\hline $1 \quad \ldots{ }_{1968}^{27-29}$ & 2 & 190 & 570 & $\begin{array}{l}\text { Degasified, } \\
\text { dosed with } \\
\text { H.SO, and }\end{array}$ \\
\hline $2-\ldots{ }_{1968}{ }^{12-14}$ & 2 & 385 & 1,118 & $\begin{array}{l}\mathrm{NazS}_{3 .} \\
\text { Dosed with } \\
\mathrm{H}_{2} \mathrm{SO}_{4} \text { and }\end{array}$ \\
\hline 3 - --.-Mar. $25-27$, & 3 & 185 & 840 & Degasified. \\
\hline $4 \quad-\ldots-$ Apr. $_{1968}^{16-19}$ & 3 & 390 & 1,655 & Nonew. \\
\hline 5 - 2 -... Feb. 17-19, & 2 & 400 & 1,200 & $\begin{array}{l}\text { Dosed with } \\
\mathrm{H}_{:} \mathrm{PO}_{4} \text {. }\end{array}$ \\
\hline $\begin{array}{l}6 \\
-\ldots-\text { Sept. }_{197} \\
19-17 \text {, }\end{array}$ & 4 & 395 & 2,281 & None. \\
\hline \multicolumn{5}{|c|}{ Reclaimed Water } \\
\hline $\begin{array}{lll}\text { RW1 } & \text {--..-Oct. } \\
1968 & \text { O-10, } \\
1968\end{array}$ & 2 & 200 & 616 & Degasified. \\
\hline RW2 ---Dec. 10-12, & 2 & 350 & 1,063 & Degasified. \\
\hline RW3 & 2 & 350 & 1,066 & None. \\
\hline RW4 $\ldots$ May $_{1969}$ & 10 & 360 & 5,247 & None. \\
\hline RW5 _-_.-. Sept. $159-25$, & 10 & 350 & 5,117 & Degasified. \\
\hline RW6 --- Mar, 17-19, & 2 & 340 & 1,133 & None. \\
\hline RW7 : --.- Apr. 14-May & 33 & 200 or 350 & 13,970 & None. \\
\hline RW8 --.-N Nov. ${ }_{1970}^{30-D e c . ~}$ & 10 & 340 & 4,930 & Unchlorinated. \\
\hline RW9 --.- Apr. 27-May & 10 & 355 & 5,156 & None. \\
\hline RW10 $\ldots$ Nov. $1-11$, & 10 & 350 & 5,180 & $\begin{array}{l}\text { Bypassed } \\
\text { carbon } \\
\text { adsorbers. }\end{array}$ \\
\hline RW10A _....Jan. $10-14$, & 4 & 350 & 2,000 & Unchlorinated. \\
\hline RW11 $\quad-\ldots-$ Mar. $_{1972}^{6-16,}$ & 10 & 350 & 5,124 & $\begin{array}{l}\text { Dosed with } \\
\mathrm{NasS2}_{3} \mathrm{O}_{3}\end{array}$ \\
\hline RW12 -..-June 5-15, & 10 & 355 & 5,050 & Dosed with \\
\hline $\begin{array}{c}\text { RW13 : } \ldots \text { Oct. } 24,1972- \\
\text { May } 11, \\
1973\end{array}$ & 84.5 & 355 & 41,695 & None. \\
\hline
\end{tabular}

depending on whether the degasifier was used. Selected chemical treatments were applied to the water (table 1) to test their effect on well clogging or on geochemical reactions. Later, during injection tests using reclaimed water, two additional tests were made in which public-supply water was injected for 2 and 4 days. The public-supply water experiments were run to test hypotheses concerning geochemical reactions. (See Ragone, 1977.)

The same kinds of measurements that were made in the pumping tests were also made during the injection tests. However, in some tests, water-level measurements in the injection well (N7884) and in two observation wells (N7885, N7886) were made with water and (or) mercury manometers, depending on the head buildup, instead of with float-activated recorders or tapes. 


\section{INJECTION EXPERIMENTS WITH RECLAIMED WATER}

Thirteen injection experiments with reclaimed water were done between October 1968 and May 1973. (See table 1.) These tests ranged in duration from 2 days to 6 months. The usual injection rate was $350 \mathrm{gal} / \mathrm{min}$. Except for brief shutdowns during a few of the tests, water was injected continuously in all tests but RW13. Injection in test RW13 was discontinuous because planned weekend shutdowns, equipment breakdowns, and short periods of backflushing for well redevelopment divided the injection period into 18 separate segments (table 2). A total of $42 \mathrm{Mgal}$ was injected during test RW13.

In all tests but RW6, including the tests using public-supply water, water was pumped into the injection well through the injection line entering the well at a depth of 192 feet. (Details are given by Koch and others, 1973, p. B3.) In test RW6, water was injected through the injection line entering the well at land surface. Because disruptive vibrations were caused by the impact of the water stream on pipes suspended in the well when water was injected into the well at land surface, the surface-injection route was not used in any other tests. The third possible injection route-through the column of the redevelopment pump-was not used at all.

Chemical quality of water was purposely varied in the tests using public-supply water and seven of the tests using reclaimed water to evaluate the significance of water quality on various aspects of the injection regime (table 1 ).
The injection rate was monitored with the magnetic flowmeter mentioned earlier and calibrated volumetrically in each test. Water-level measurements in the injection well and in selected observation wells were made in all tests with a combination of automatic float-activated water-level recorders, water and (or) mercury manometers, and pressure gages. Flowmeter surveys in the screened part of the injection well were made during the early tests but were discontinued in the later tests because they turned out to be of questionable value. (See section "Flowmeter Surveys" and fig. 10.)

\section{WELL-REDEVELOPMENT EXPERIMENTS}

Several methods of redevelopment were tried in an attempt to restore well capacity, which decreased to some degree during each injection test. Prolonged pumping of the well with a deep-well turbine pump, which is an integral part of the injection-well installation (see Koch and others, 1973, p. B7, for details), was done either alone or in combination with some other technique. The well was pumped at different rates, ranging from 100 to $1,000 \mathrm{gal} / \mathrm{min}$, but 400 to $500 \mathrm{gal} / \mathrm{min}$ was most common.

On many occasions, the well was surged by a cyclic starting and stopping of the pump at short intervals; this pumping was generally at the maximum rate of $1,000 \mathrm{gal} / \mathrm{min}$. After one injection test, when the deep-well turbine pump had to be removed for repair of the well casing, the well was surged by swabbing with a double surge block in combination with air-lift pumping.

TABLE 2.-Injection data from test $R$ W13, October 1972 to May 1973

[ Injection rate $350 \mathrm{gal} / \mathrm{min}$. unless otherwise noted. Modified from Sulam, 1973]

\begin{tabular}{|c|c|c|c|c|c|c|c|c|c|c|}
\hline & \multirow{2}{*}{ Segment } & \multirow{2}{*}{$\begin{array}{c}\text { Date } \\
\text { started }\end{array}$} & \multirow{2}{*}{$\begin{array}{l}\text { Date } \\
\text { ended }\end{array}$} & \multirow{2}{*}{$\begin{array}{l}\text { Total } \\
\text { number } \\
\text { of days }\end{array}$} & \multirow{2}{*}{$\begin{array}{c}\text { Total } \\
\text { gallons } \\
\text { injected }\end{array}$} & \multirow{2}{*}{$\begin{array}{l}\text { Cumulative } \\
\text { gallons } \\
\text { injected }\end{array}$} & \multirow{2}{*}{$\begin{array}{c}\text { Head } \\
\text { buildup } \\
\text { (ft) }\end{array}$} & \multicolumn{3}{|c|}{$\begin{array}{c}\text { Specific capacity } \\
{[(\mathrm{gal} / \mathrm{min}) / \mathrm{ft}]}\end{array}$} \\
\hline & & & & & & & & Start & End & Change \\
\hline 1 & $-\ldots \ldots$ & $10-24-72$ & $10-27-72$ & 3 & $1,598,400$ & $1,598,400$ & 19.5 & 23.7 & ${ }^{1} 18$ & -5.7 \\
\hline 2 & ------- & $11-7-72$ & $11-17-72$ & 10.5 & $5,192,400$ & $6,790,800$ & 28.5 & 25.8 & 12.3 & -13.5 \\
\hline 3 & -------- & $11-20-72$ & $11-22-72$ & 2.5 & $1,213,600$ & $8,004,400$ & 28.5 & 12.3 & 12.3 & 0 \\
\hline 4 & -------- & $11-27-72$ & $12-8-72$ & 11.5 & $5,657,300$ & $13,661,700$ & 52.6 & 12.3 & 16 & -6.3 \\
\hline 5 & ------- & $12-13-72$ & $12-15-72$ & 2.5 & $1,246,800$ & $14,908,500$ & 30.8 & 14.7 & 11.3 & -3.4 \\
\hline 6 & -------- & $12-19-72$ & $12-21-72$ & 2.5 & $1,255,400$ & $16,163,900$ & 36.0 & 11.3 & $\begin{array}{ll}1 & 9.7\end{array}$ & -1.6 \\
\hline 7 & -------- & $1-3-73$ & 1-12-73 & 9.5 & $4,706,700$ & $20,870,600$ & 43.6 & 11.7 & 7.9 & -3.8 \\
\hline 8 & -------- & $1-15-73$ & $1-19-73$ & 4.5 & $2,246,600$ & $23,117,200$ & 48.7 & 7.9 & $\begin{array}{ll}1 & 7.1\end{array}$ & -.8 \\
\hline 9 & -------- & $1-29-73$ & $2-4-73$ & 6.5 & $3,206,300$ & $26,323,500$ & 48.7 & 12.8 & $\begin{array}{ll}1 & 7.1\end{array}$ & -5.7 \\
\hline 10 & $\ldots-\ldots \ldots$ & $2-6-73$ & $2-9-73$ & 3 & $1,470,600$ & $27,794,100$ & 50.2 & 13.0 & $\begin{array}{ll}1 & 6.9\end{array}$ & -6.1 \\
\hline 11 & ------ & $2-10-73$ & $2-10-73$ & .33 & 149,400 & $27,943,500$ & 30.2 & 11.6 & & \\
\hline 12 & & $2-12-73$ & $2-13-73$ & .67 & 324,700 & $28,268,200$ & 224.8 & --- & $\left({ }^{1}\right)$ & \\
\hline 13 & 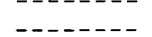 & $3-12-73$ & $3-16-73$ & 4.5 & $2,207,700$ & $30,475,900$ & 38.3 & 12.6 & 9.2 & -3.4 \\
\hline 14 & $---\ldots$ & $3-19-73$ & $3-30-73$ & 11.5 & $5,678,200$ & $36,154,100$ & 46.2 & 9.2 & 8.1 & -1.1 \\
\hline 15 & --.---.-- & $4-2-73$ & $4-6-73$ & 4 & $1,963,000$ & $38,117,100$ & 50.1 & 8.1 & 17.0 & -1.1 \\
\hline 16 & ------- & $4-9-73$ & $4-9-73$ & .5 & 233,500 & $38,350,600$ & 32.8 & 13.3 & ${ }^{1} 11$ & -2.3 \\
\hline 17 & & $5-2-73$ & $5-4-73$ & 2.5 & $1,177,400$ & $39,528,000$ & 33.8 & 12.7 & 9.8 & -2.9 \\
\hline 18 & & $5-7-73$ & $5-11-73$ & 4.5 & $2,166,700$ & $41,694,700$ & 40.9 & 9.8 & 8.6 & -1.2 \\
\hline
\end{tabular}

'Redevelopment. (See table 8.)

Injection rate reduced to $200 \mathrm{gal} / \mathrm{min}$

: Hydrochloric acid added. 
Several chemical treatments were applied to observe their effectiveness in restoring specific capacity. During two tests, the well was dosed with hydrochloric acid; during other tests it was dosed with bactericides. Solutions of an ammonium compound were used in two tests; solutions of sodium hypochlorite were used in three tests.

\section{EFFECT OF INJECTION ON AQUIFER HEAD}

\section{THEORETICAL HEAD BUILDUP}

When water is injected into an aquifer through a well, a cone of elevation, or mound, forms around the well in the shape of an inverted cone of depression. Theoretically, in a confined isotropic homogeneous aquifer of infinite areal extent, the cone of elevation would be the mirror image of the cone of depression, given equal time periods of and rates of pumping and provided that the water injected had the same viscosity as the native ground water.

Although the injection zone at Bay Park differs somewhat from the theoretical model (Vecchioli and others, 1974), the observed hydraulic response closely approximated the theoretical response within a radius of 200 feet of the injection well, which is the limiting radius of observation at Bay Park. Accordingly, the shape of the cone of elevation, and water levels in wells within the cone at any time, should be predictable from observations made during pumping tests. Any departure from predicted response, after all appropriate corrections are made, would indicate a change in the hydraulic characteristics of the receiving zone.

\section{OBSERVED HEAD BUILDUP}

Head-buildup data obtained at each of the observation wells tapping the Magothy aquifer and dur- ing each injection test were compared with corresponding drawdown data to evaluate the "mirror image" theory. These data were also examined for any progressive change in the hydraulic characteristics that might have occurred over the course of the injection experiments.

Values of head buildup at each well were grouped according to the type of water injected, and each group was evaluated statistically (table 3 ). Mean head-buildup values at each well and in each group of tests were compared with the drawdown value obtained from the initial pumping tests at the corresponding time. The hypothesis that the injectiontest means were the same as the pumping-test values was evaluated at the 95-percent confidence level. The hypothesis was acceptable in all instances except for observation well N7886, 20 feet from the injection well, during tests with reclaimed water.

Reasons for the difference in response at well N7886 are unclear. This well is screened in the same depth interval as the injection well and is only 20 feet from it. During the recharge tests, well N7886 was pumped at 1 to $2 \mathrm{gal} / \mathrm{min}$ for sampling. The pumping interfered slightly with the water-level observations, and corrections for the interference were not made rigorously. This interference would cause the head buildup to be low in relation to the pumping-test drawdown, and observation confirmed this. Also, throughout most of the tests using reclaimed water, for ease of computation, average tidal-efficiency and barometric-efficiency factors were applied in adjusting the observed water levels at all the wells; however, individual factors were applied to all well results during the initial pumping tests. This discrepancy adds additional uncertainty to the accuracy of the comparison.

TABLE 3.-Statistical comparison of drawdowns at observation wells after 1 day of pumping with head buildups after 1 day of injection

[Va]ues are in feet per 100 gallons per minute]

\begin{tabular}{|c|c|c|c|c|c|c|c|c|c|c|c|c|c|c|}
\hline & \multirow{2}{*}{$\begin{array}{l}\text { Obser- } \\
\text { vation } \\
\text { well } 1\end{array}$} & \multirow{2}{*}{$\begin{array}{c}\text { Initial } \\
\text { pumping } \\
\text { test }\end{array}$} & \multicolumn{6}{|c|}{ Public-supply water injection test: } & \multicolumn{6}{|c|}{ Reclaimed-water injection tests } \\
\hline & & & $\begin{array}{c}\text { Number } \\
\text { of } \\
\text { tests }\end{array}$ & $\begin{array}{l}\text { Maxi- } \\
\text { mum }\end{array}$ & $\begin{array}{l}\text { Mini- } \\
\text { mum }\end{array}$ & Mean & $\begin{array}{c}\text { Standard } \\
\text { devia- } \\
\text { tion }\end{array}$ & Result $=$ & $\begin{array}{c}\text { Number } \\
\text { of } \\
\text { tests }\end{array}$ & $\begin{array}{l}\text { Maxi- } \\
\text { mum }\end{array}$ & $\begin{array}{l}\text { Mini- } \\
\text { mum }\end{array}$ & Mean & $\begin{array}{c}\text { Standard } \\
\text { devia. } \\
\text { tion }\end{array}$ & Result 2 \\
\hline N7886 & $-----\ldots$ & 1.77 & 6 & 1.78 & 1.65 & 1.70 & 0.05 & A & 13 & 1.71 & 1.55 & 1.64 & 0.04 & $\mathbf{R}$ \\
\hline N7887 & - & .35 & 6 & .41 & .34 & .38 & .03 & A & 13 & .41 & .32 & .36 & .03 & A \\
\hline N7888 & - & .19 & 6 & .27 & .20 & .24 & .03 & A & 13 & .28 & .16 & .21 & .04 & A \\
\hline N7889 & $----1--$ & .35 & 6 & .42 & .31 & .37 & .04 & A & 13 & .41 & .30 & .36 & .03 & A \\
\hline N7890 & $----\ldots--$ & 1.06 & 6 & 1.09 & 1.00 & 1.03 & .03 & A & 13 & 1.08 & .92 & 1.00 & .04 & A \\
\hline N7891 & -...- & .20 & 5 & .22 & .28 & .26 & .03 & A & 13 & .27 & .18 & .21 & .03 & A \\
\hline N8022 & - - & .79 & 6 & .85 & .79 & .83 & .03 & A & 13 & .84 & .72 & .77 & .03 & A \\
\hline N7290 & - $-1--1---1$ & .30 & 5 & .38 & .31 & .35 & .03 & A & 12 & .38 & .29 & .33 & .03 & A \\
\hline
\end{tabular}

1 Locations are given in Koch and others (1973, fig. 8).
2 Test of hypothesis: The mean of the injection tests is equal to the man of pumping test at 95-percent confidence level. A, acceptance; R, rejection. 
On the other hand, the slightly lower head buildup observed at well N7886 during injection could reflect a slight dilation of the receiving zone in response to the increase in pore pressure. This dilation, if present, would be greatest in the vicinity of the injection well, where the disturbance was greatest. Moreover, the dilation near the injection well would be greater than the compaction that might occur near the injection well during pumping. Dilation of the receiving zone upon injection would tend to increase the hydraulic conductivity; hence, head buildup would be less than drawdown if all conditions other than direction of flow were equal.

No chronologic trend was observed in headbuildup values. Also, drawdown data from a pumping test (well N7886) made after conclusion of the injection tests were virtually identical to those from the initial pumping tests (fig. 2) except for drawdown in the injection well (fig. 3). Differences in drawdown values of the injection well reflect residual partial clogging of the well, as discussed in the later section "Injection-Well Performance." These observations indicate that no significant cumulative changes in the hydraulic properties of the aquifer resulted from the experiments.

Comparison of the slope of the cone of elevation formed during injection with the slope of the cone of depression formed during pumping (fig. 4) shows the two to be similar. The slightly discrepant data from well N7886, 20 feet from the injection well, indicate the cone of elevation to be slightly smaller than the cone of depression and to have a slightly lesser slope.

Figure 5 illustrates the head-buildup distribution that was observed vertically and radially in the Magothy aquifer when water was injected at a rate of $350 \mathrm{gal} / \mathrm{min}$. In layers above the Magothy aquifer that are less than 100 feet below land surface, waterlevel fluctuations (fig. 6) indicated no head buildup. A small amount of head buildup in these layers probably occurred but was masked by water-level fluctuations caused by other factors. Head buildup in all zones observed was virtually stable after 1 day of injection.

\section{INJECTION-WELL PERFORMANGE}

\section{CHANGES IN SPECIFIC GAPACITY}

Performance of the injection well during the injection experiments can be evaluated in terms of the specific capacity of the well. When water is withdrawn from a well, the specific capacity of the well is the rate of yield, in gallons per minute per foot of drawdown; when water is injected into a well, the specific capacity of the well is the rate of injection per foot of head buildup. If no well clogging oc-

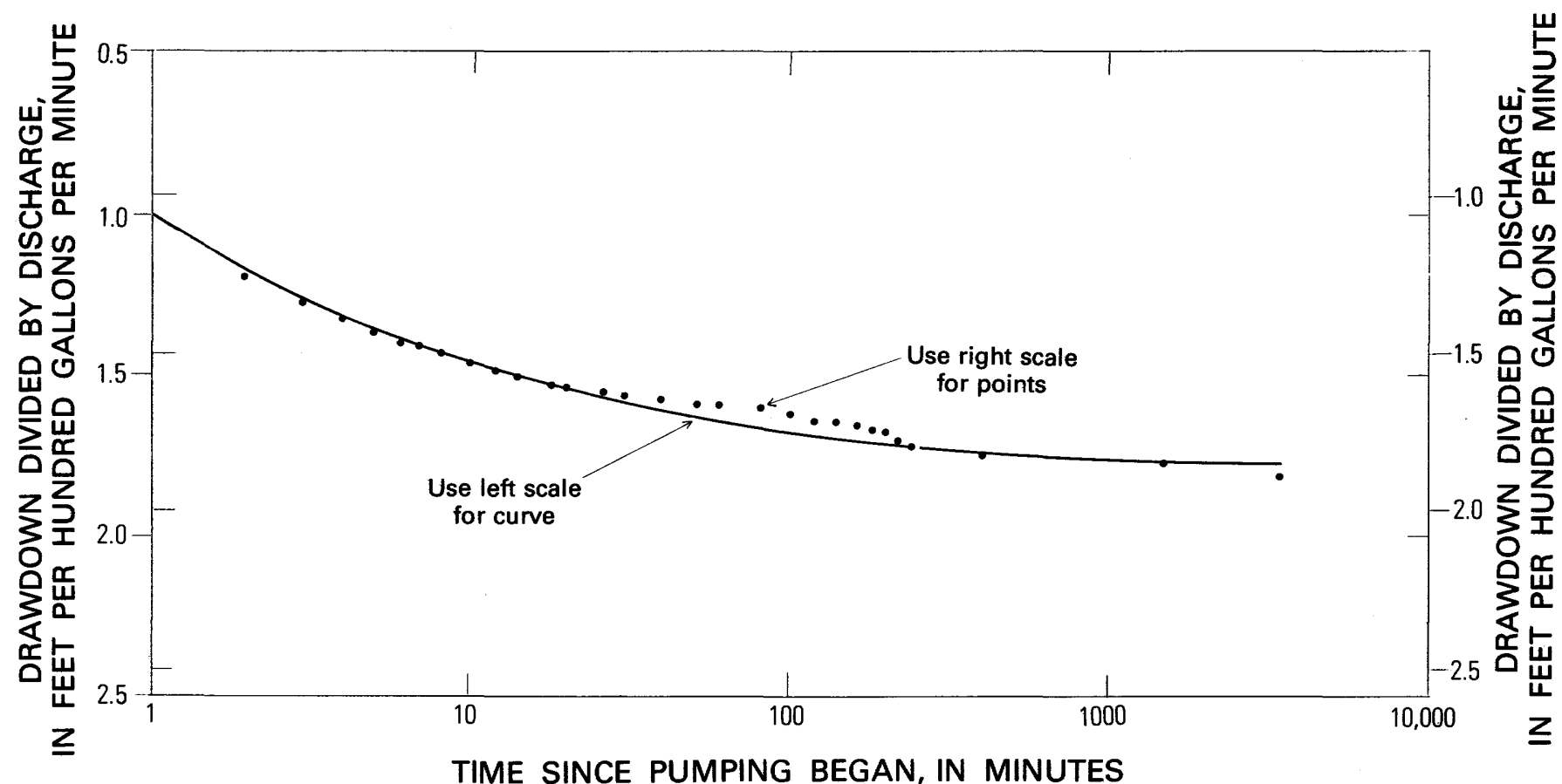

Figure 2.- Time drawdown curves for observation well $20 \mathrm{ft}$ from injection well from measurements taken during pumping tests before any injection and after final injection test. Solid curve, pumping tests before injection; solid circles, pumping test after last injection. 


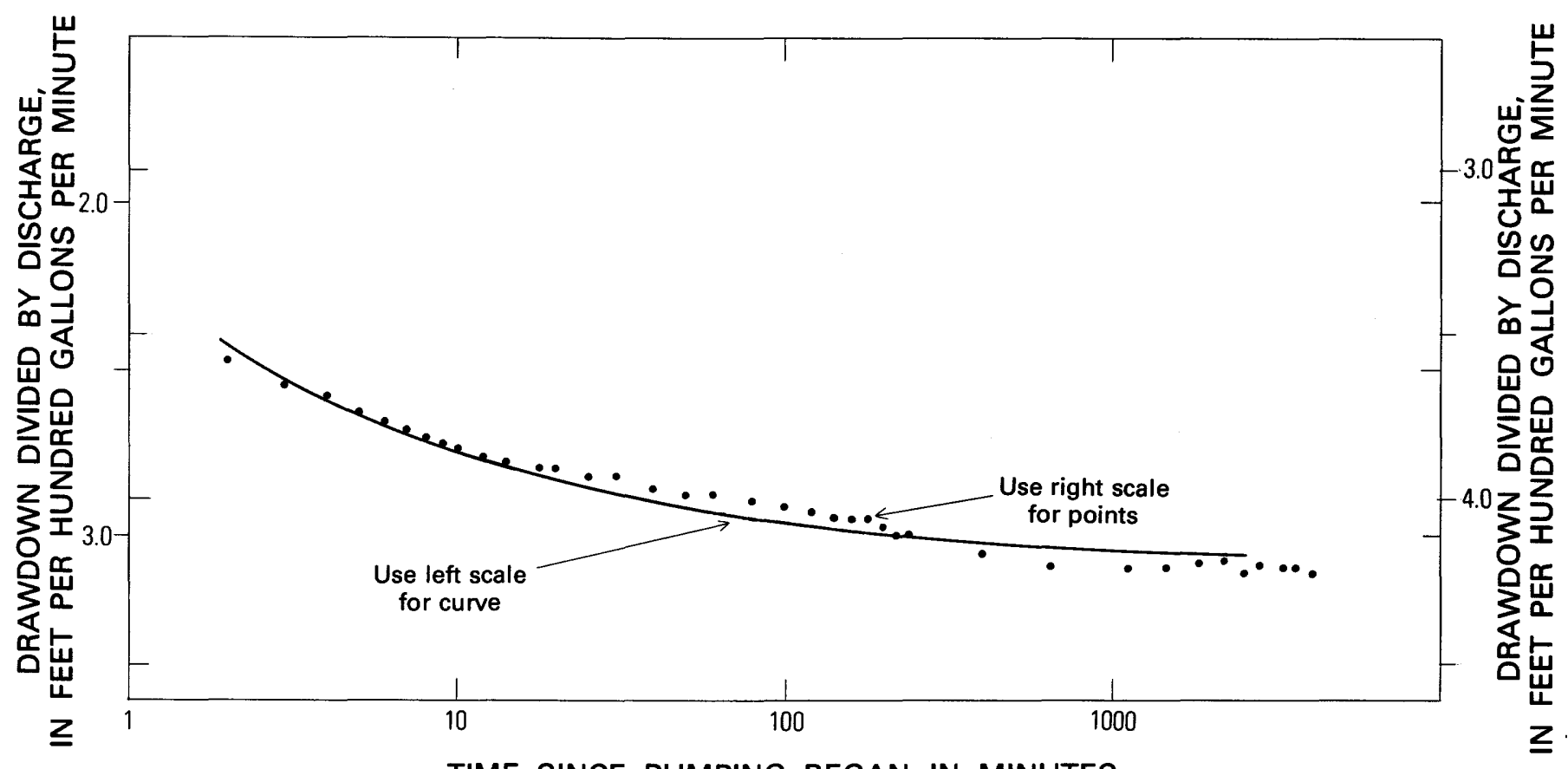

TIME SINCE PUMPING BEGAN, IN MINUTES

FIGURE 3.-Time drawdown curves for injection well from measurements taken during pumping tests before any injection and after final injection test. Solid curve, pumping tests before injection; solid circles, pumping test after last injection.

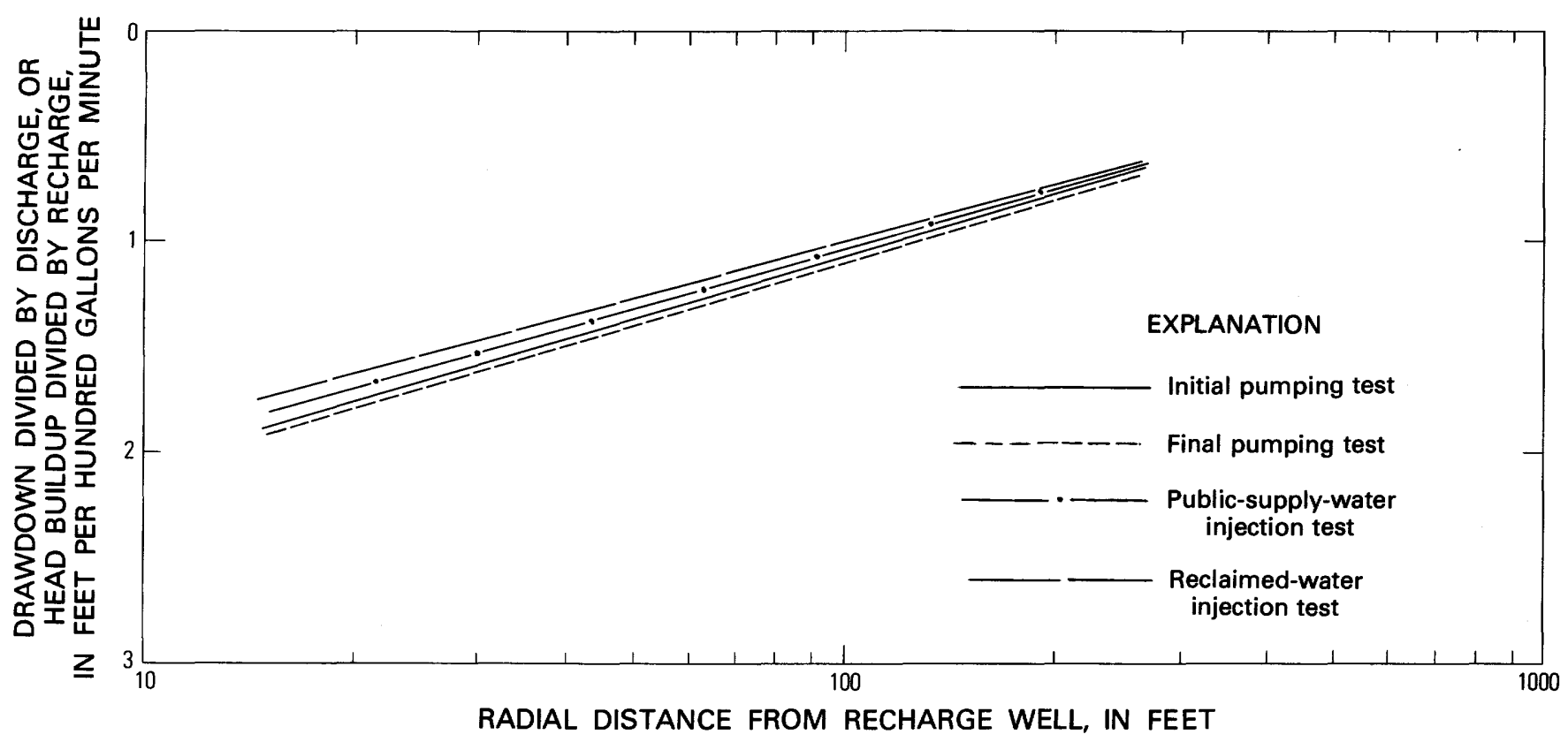

Figure 4.- Relation between distance from injection well and drawdown or head buildup after 1 day, at pumping rate of $350 \mathrm{gal} / \mathrm{min}$. (Based on water levels in the observation wells 20,100 , and $200 \mathrm{ft}$ from injection well.)

curs, the head buildup observed in the well during injection should theoretically equal the drawdown that would occur if the well were pumped at the same rate, other things being equal. Head buildup in excess of that amount is an indication of clogging of the well and (or) the aquifer and is reflected in a decrease in the injection specific capacity of the well.

The rate of clogging differed considerably from test to test and within individual tests, as shown by the data in table 4 for test RW13. The average rate 


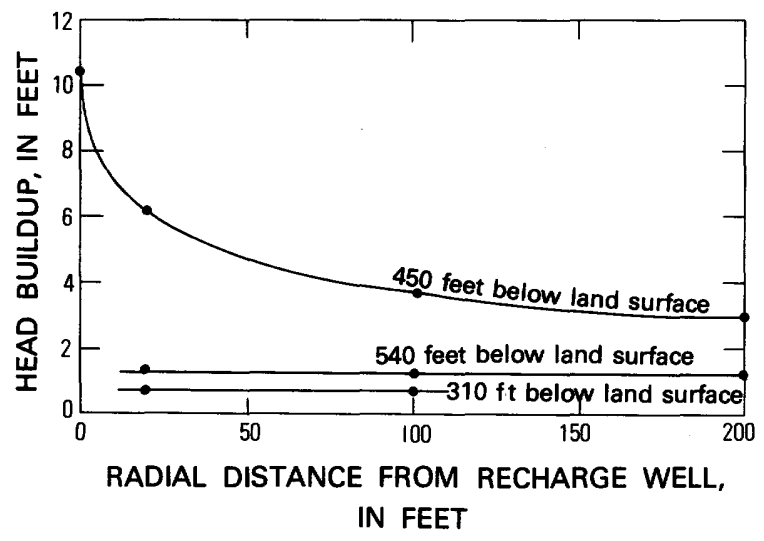

F'IGURE 5.-Equilibrium head buildup at selected depths and distances from injection well. (Based on water levels in observation wells 20,100 , and $200 \mathrm{ft}$ from injection well and at injection rate of $350 \mathrm{gal} / \mathrm{min}$.) (From Vecchioli and others, 1975, p. 207.)

of clogging observed during test RW13 was approximately 4 feet of excessive head buildup per 1 Mgal. If only the recharge episodes greater than $3 \mathrm{Mgal}$ are considered, however, the average rate of clogging was approximately 3 feet of excessive head buildup per $1 \mathrm{Mgal}$. This value is probably the more representative of long-term clogging rates.

Initially, the pumping specific capacity of the injection well was $32.8(\mathrm{gal} / \mathrm{min}) / \mathrm{ft}$ after 2 days of

TABLE 4.-Clogging rates in test $R W 13$, October 24,1972 , to May 11, 1973

[Modified from Vecchioli and others, 1975, p. 208]

\begin{tabular}{|c|c|c|c|}
\hline $\begin{array}{l}\text { Reclaimed } \\
\text { water volume } \\
\text { injected } \\
(\text { Mgal })\end{array}$ & & $\begin{array}{c}\text { Excessive } \\
\text { head } \\
\text { buildup } \\
\text { (ft) }\end{array}$ & $\begin{array}{c}\text { Head buildup } \\
\text { per injection } \\
\text { volume } \\
\text { (ft/Mgal) }\end{array}$ \\
\hline 1.598 & - - - - - - - - - & 4.0 & 2.5 \\
\hline 12.063 & - - - & 32.5 & 2.7 \\
\hline 2.502 & 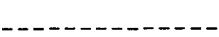 & 12.3 & 4.9 \\
\hline 6.953 & 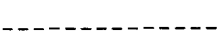 & 19.4 & 2.8 \\
\hline 3.206 & $-\ldots----$ & 22.0 & 6.9 \\
\hline 1.471 & $---n-\ldots$ & 23.8 & 16.2 \\
\hline 9.849 & - & 22.2 & 2.3 \\
\hline 3.344 & - - - & 13.1 & 3.9 \\
\hline
\end{tabular}

${ }^{1}$ Amount of head buildup attributed to well clogging.

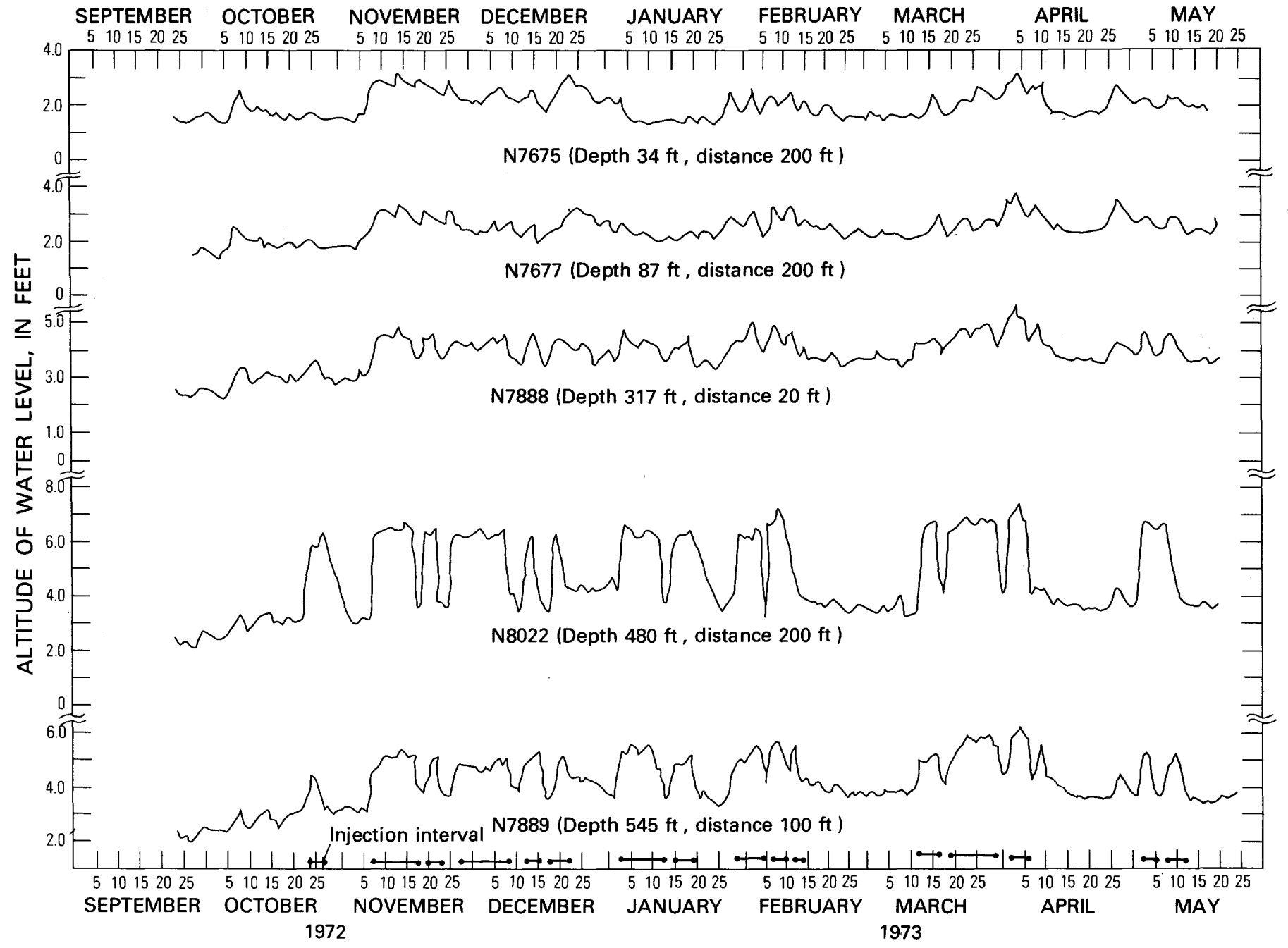

Figure 6.-Hydrographs of selected observation wells during injection test RW13, October 24, 1972 , to May $11,1973$. 
pumping. Both the specific capacity and drawdown changed very little after 1 day of pumping and became virtually stable after 2 days (fig. 3 ). In fact, the difference between the specific capacity after 4 hours of pumping and after 2 days was only a few tenths of a unit. Hence, evaluations of long-term changes in specific capacity during injection were made from data from shorter pumping tests. Pumping specific capacity was determined before and after each injection experiment.

The injection specific capacities observed in each injection test were lower than the corresponding pumping specific capacities obtained before each test, as shown by data in columns 1 and 2 of table 5 . Even after adjustments for differences in water temperature, as discussed firther on, the injection specific capacities were lor. - than the pretest values in all tests, and the pretest specific capacity of 32.8 ( $\mathrm{gal} / \mathrm{min}$ ) $/ \mathrm{ft}$ was not restored during the injection experiments. This indicates that some clogging of the well and (or) the contiguous part of the aquifer had occurred in each injection test.

\section{EFFECT OF TEMPERATURE ON SPECIFIC GAPACITY}

Temperature of native water in the 420-to 480foot interval (recharge zone) of the Magothy aquifer is $15^{\circ} \mathrm{C}$. Temperature of water injected varied from test to test, ranging from $9^{\circ} \mathrm{C}$ in one of the tests using public-supply water to $23^{\circ} \mathrm{C}$ in one of the tests using reclaimed water (table 5). Adjustments were made in the observed specific capacities to correct for the temperature differences because (1) the viscosity of the water is inversely related to the temperature, (2) the hydraulic conductivity of the aquifer is inversely related to the viscosity of the water, and (3) the specific capacity of the well is directly related to the hydraulic conductivity of the aquifer.

Observed specific capacities were adjusted according to a method described by G. D. Bennett (written commun., 1969). In Bennett's method, the extent of the cylinder of injected water (the temperature of which differs from that of the aquifer) is taken into consideration. The head-buildup correction needed at any time as a result of temperature difference is calculated from the equation:

$$
s_{w T t}-s_{w t}=\left(\frac{1}{K_{L T}}-\frac{1}{K_{L}}\right) \frac{2.3 Q}{2 \pi D} \log \left(\frac{r_{T t}}{r_{w}}\right),
$$

where $s_{w T t}-s_{w t}=$ head buildup at injection well for injection of water temperature $T$, at time $t$, minus head buildup in

TABLE 5.-Unadjusted and adjusted end-of-test specific capacities determined in each injection test

[Specific capacities are in gallons per minute per foot]

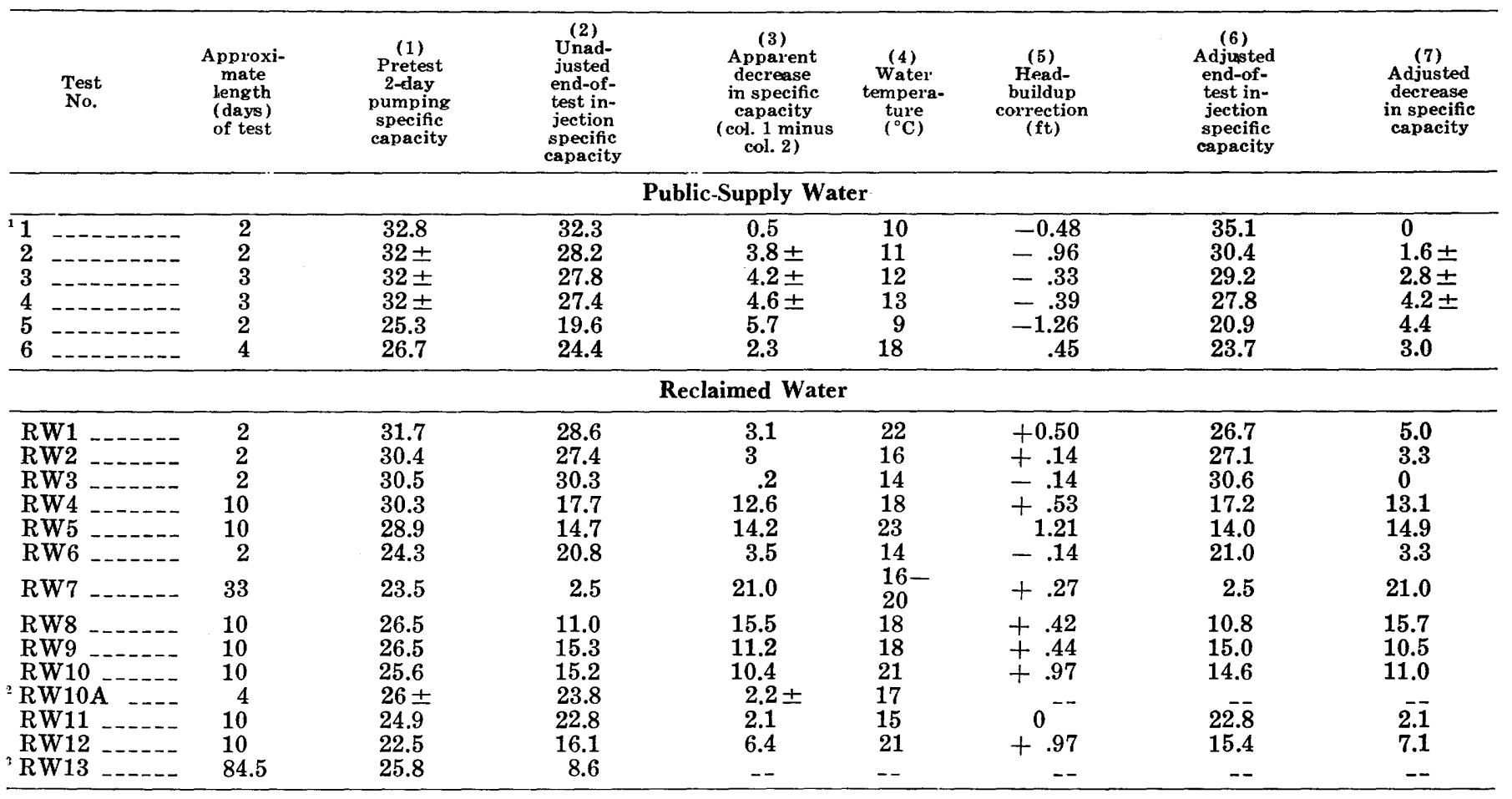

1 Rate control poor: specific-capacity data uncertain.

: Adjustments for temperature not made. Water injected in previous test not repumped. interspersed between injection segments. End-of-test specific capacity is specific capacity at end of last injection segment. 
injection well for formation water, at time $t$, in feet,

$K_{I, T} \quad=$ lateral hydraulic conductivity to injection water of temperature $T$, in feet per day,

$K_{L} \quad=$ lateral hydraulic conductivity to formation water, in feet per day,

$Q \quad=$ injection rate, in cubic feet per day,

$D \quad=$ thickness of injection stratum, in feet,

$r_{T t} \quad=$ radius of cylinder of injected water of temperature $T$, at time $t$ after start of injection, in feet, and

$r_{w} \quad=$ radius of injection well, in feet.

The lateral hydraulic conductivity of the formation to injection water at temperature $T, K_{L T}$, is obtained by multiplying the hydraulic conductivity to formation water, $K_{L}$, by $\frac{\mu}{\mu_{T}}$, where $\mu$ is the viscosity of the formation water and $\mu_{T}$ is the viscosity of the injected water.

In applying the temperature adjustments, one must make several simplifying assumptions that are not entirely valid. Hence, the adjustments to the specific capacities as given in table 5 represent extreme values; the actual adjustments should probably be somewhat less. Accordingly, the true end-oftest specific capacity probably lies somewhere between the observed value and the adjusted value.

\section{WELL CLOGGING}

Clogging of injection wells results from three general types of action-biological, mechanical, and chemical (American Water Works Association, Task Group 2440-R on Artificial Ground Water Recharge, 1965). Individual mechanisms of each type can operate separately or together to cause clogging. Some may clog wells abruptly, whereas others may do it gradually. Identification of the clogging mechanism(s) is essential for selection of proper treatments to remedy the clogging and to prevent or minimize its recurrence.

Biological clogging may result from either the growth of foreign organisms introduced by injection or from the growth of indigenous organisms stimulated by nutrients in the injected water. These growths may occur within the well, at the aquifer face, or within the aquifer at some distance from the well. According to Ehrlich (1972, p. 299), bacteria are the organisms of main concern in the injection well/aquifer regimen.
Mechanical or physical clogging can be caused in several ways. Reversing the direction of water movement in the aquifer adjacent to the injection well may rearrange particles, which could result in denser packing and a consequent reduction in hydraulic conductivity. Particles suspended in the injected water may filter out and accumulate either within the gravel pack, at the interface between the gravel pack and the aquifer, or within the interstices of the aquifer. The particles may be introduced by the injected water or they may come from erosion of residual drilling mud that was not removed completely during well development. Microorganisms carried by the water may also plug the gravel-pack and (or) aquifer interstices in the same manner as inorganic particles. Air bubbles entrained in the injected water or dissolved gases that are liberated once the water is within the aquifer may cause binding of the aquifer.

Chemical clogging may result from chemical reactions between the injected water and the aquifer particles and (or) the native water. Ion-exchange reactions involving injected water having high sodium concentrations (generally more than 50 percent of cation concentration) may result in a dispersal of clay particles, which may plug interstices. Mineral species in solution in either the injected or native water may become unstable upon mixing of the two waters, with the result that a chemical precipitate may form. The precipitate may act as a cement and seal aquifer interstices. Carbonates, sulfides, and hydroxides-commonly of iron-are the groups generally of concern with respect to chemical clogging.

A considerable part of the Bay Park study was devoted to identification of clogging mechanisms and methods of either controlling these mechanisms or remedying the resultant clogging. Mechanical clogging predominated in this study; biological clogging was significant only when the reclaimed water was not chlorinated before injection. Some chemical clogging probably occurred, but its effect on excessive head buildup was greatly overshadowed by that of mechanical clogging. Evidence for these conclusions follows.

\section{MECHANICAL CLOGGING}

Mechanical clogging resulted mainly from the filtration, onto the aquifer face, of suspended matter carried by the injectant. Because determination of the very low suspended-solids concentration in the injected water is difficult, turbidity was used as a 


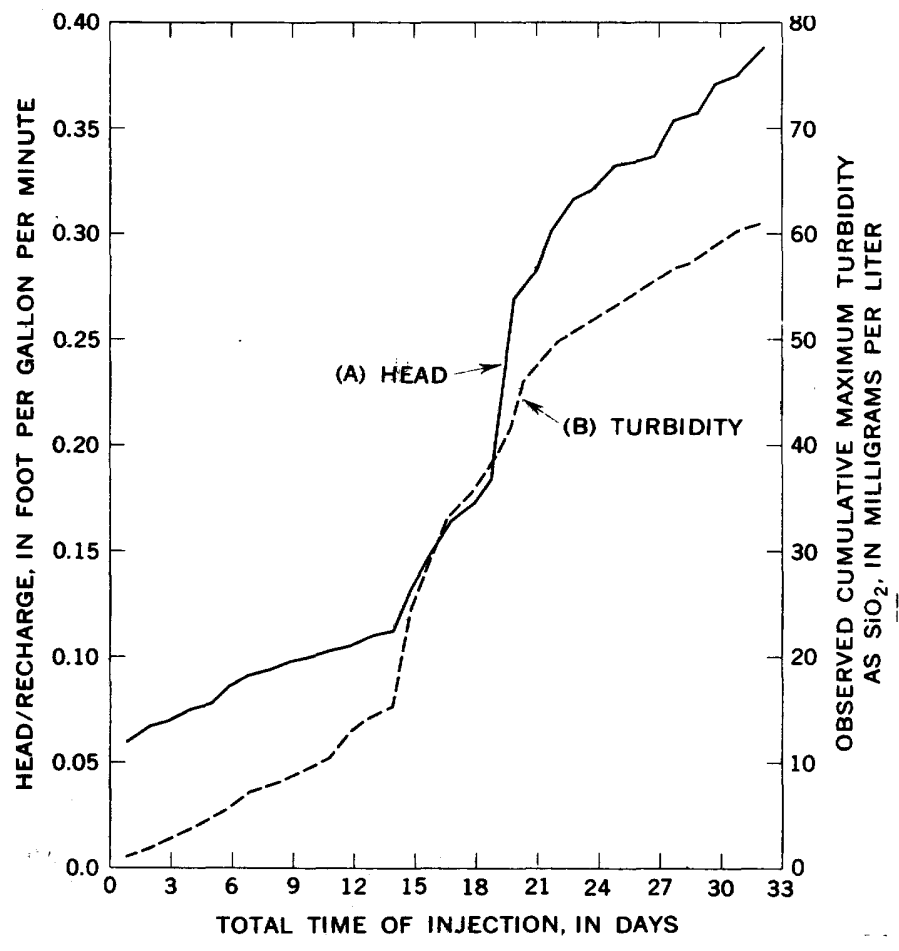

Figure 7.-Comparison of head buildup and turbidity during test RW7, April 14 to May 17, 1970. A, head buildup divided by rate of injection; $B$, cumulative maximum turbidity. (From Ehrlich and others, 1972, p. B243.)

measure of the variations in suspended-solids concentration.

Figure 7 shows the relation of turbidity to clogging of the injection well during test RW7. In this figure, the maximum turbidity values observed each day are cumulated and compared with the specific head buildup ( $\Delta$ head/injection rate), which is the reciprocal of the specific capacity during injection. Similarity of the two curves is readily apparent. Specific head buildup would have leveled off after the second day if there had been no clogging.

The fine- to medium-grained character of the injection stratum renders it very effective in filtering particulate matter from the injectant. Moreover, considering that the injection-well complex has a diameter of 3 feet and a screen length of 62 feet, the aquifer face was loaded at a rate of approximately $0.6(\mathrm{gal} / \mathrm{min}) / \mathrm{ft}^{2}$ when the injection rate was 350 $\mathrm{gal} / \mathrm{min}$. Thus, even though levels of suspendedsolids concentration (in turbidity units) were generally below $1 \mathrm{mg} / \mathrm{L}$ (milligram per liter) accumulation of the injected solids at the aquifer face was considerable. Particulate accumulation in the gravel pack caused little clogging; heads in an observation well screened in the gravel pack differed from those in the injection well by only about 0.1 foot through- out all tests but RW8. (Reasons for anomalous heads in test RW8 are discussed in section "Biological Clogging.")

Variations in turbidity of the water injected in tests RW3 through RW13 (except RW6) are summarized in table 6 , together with the corresponding decrease in specific capacity per million gallons of water injected. Little correlation is evident between mean turbidity and decrease in specific capacity. However, in tests in which the maximum turbidity values were less than $1 \mathrm{mg} / \mathrm{L}$, decrease in specific capacity was slight. Slugs of injectant having turbidity greater than $1 \mathrm{mg} / \mathrm{L}$ seemed to affect the well's specific capacity to a disproportionately greater degree than water of lower turbidity.

The sensitivity of the rate of clogging to seemingly small changes in turbidity is seen in figure 8 . In test RW9, head buildup increased at a low rate in the early part of the test, when the turbidity of the injectant averaged $0.1 \mathrm{mg} / \mathrm{L}$ and did not exceed 0.75 $\mathrm{mg} / \mathrm{L}$. However, in the latter part of the test, when turbidity increased to an average of $0.6 \mathrm{mg} / \mathrm{L}$ and reached a maximum of $1.5 \mathrm{mg} / \mathrm{L}$, the rate of head buildup increased sharply.

The amount of clogging caused by a given suspended-solids concentration generally depended on the degree to which the well was clogged at the time. A given suspended-solids load caused less head buildup when specific capacity was high than when it was much lower. This relation was definable only in very general terms. However, a crude relation was developed between suspended-solids concentration and excessive head buildup within the range of specific capacity observed during test RW13; this relation is shown in figure 9. Only injection periods of 1 week or longer, uninterrupted by redevelopment, were considered. Injected suspended-solids load was computed from turbidity determinations. Specific capacity of the injection well throughout test RW13 ranged from $6(\mathrm{gal} / \mathrm{min}) / \mathrm{ft}$ to $13(\mathrm{gal} / \mathrm{min}) / \mathrm{ft}$, except during the first several days of the test. Over this range of well efficiency, the unit change in head, in feet per million gallons, was 0.74 times the change in suspended-solids load, in pounds per million gallons.

Well clogging caused by the release of entrained air or dissolved gases from the injected water was not observed. The reclaimed water injected was degasified in two of the 2-day tests and in one 10-day test, and, contrary to expectations, the excessive head buildup in those tests was higher than in comrarable tests in which the water was not degasified. Any minor beneficial influence of degasification was 


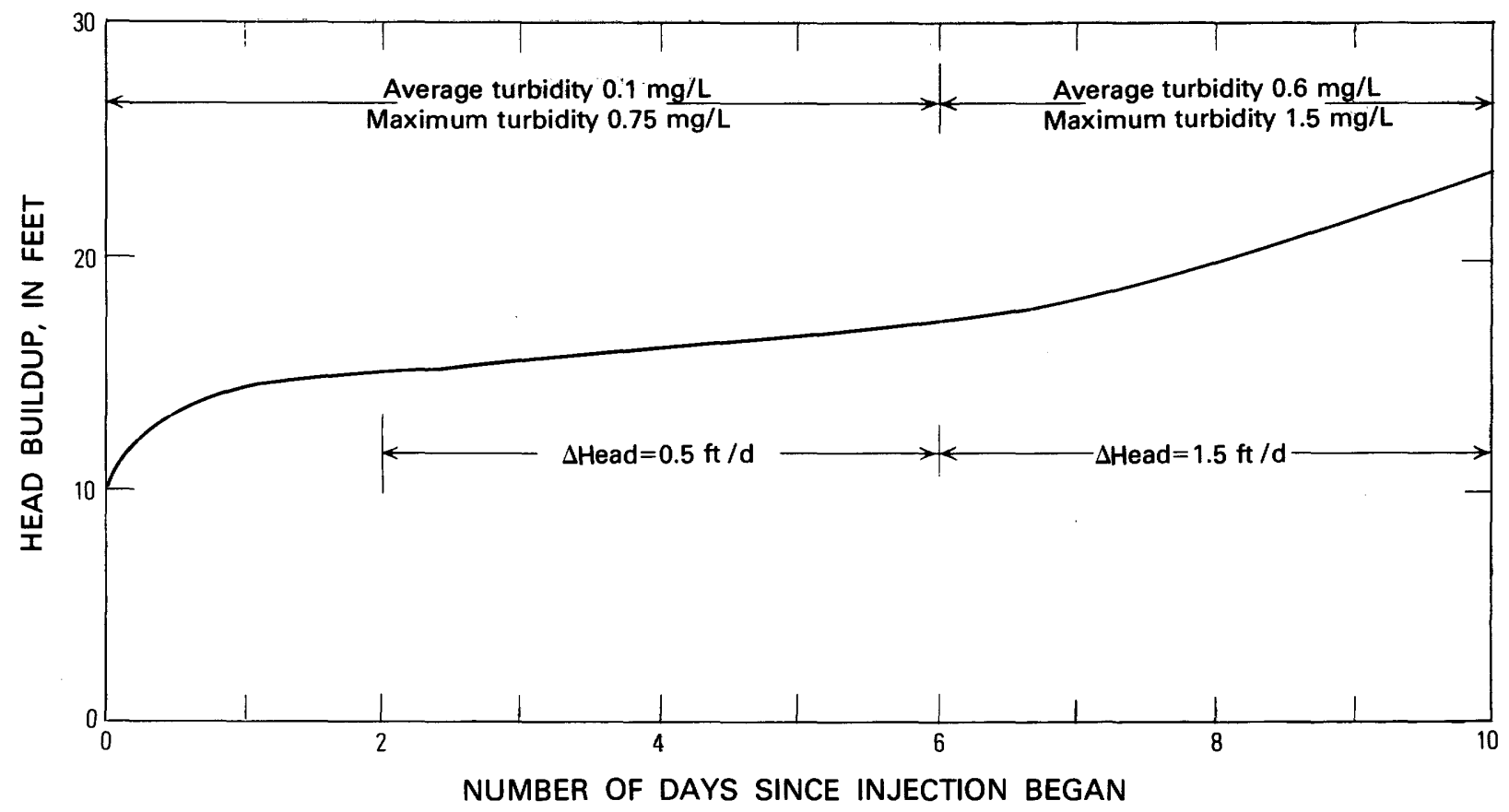

Figure 8.- Head buildup in injection well during test RW9, April 27 to May 7, 1971, and turbidity of water injected. (Modified from Vecchioli, 1972, p. 93.)

TABLE 6.-Turbidity of injected water in tests $R W 3-R W 13$ (except $R W 6$ ) and corresponding decrease in specific capacity

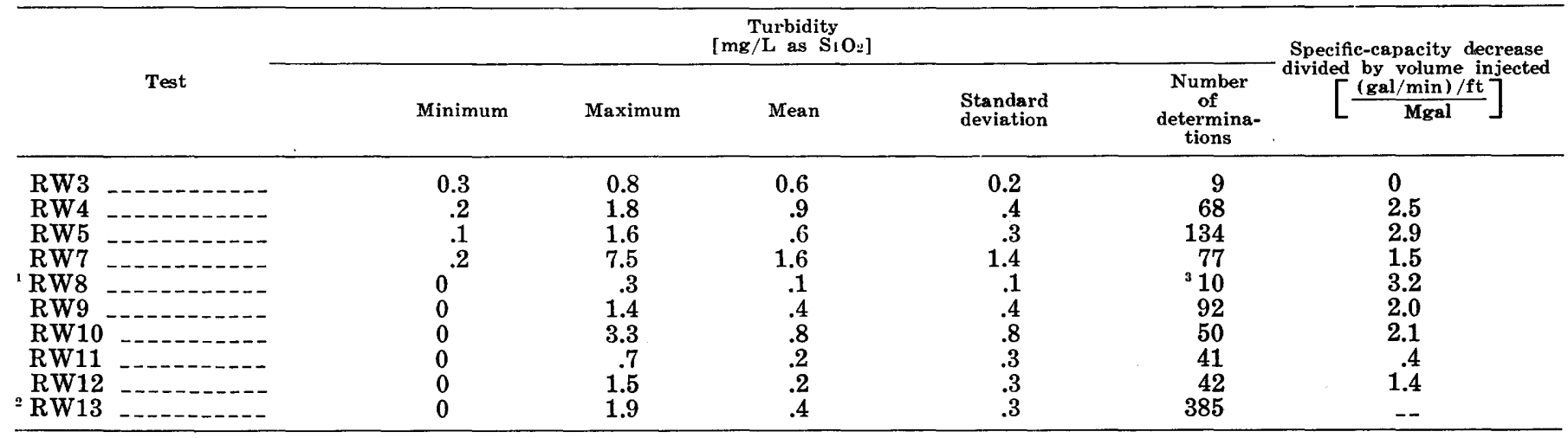

Injection water not chlorinated.

Injection discontinuous. See table 2 and figure 9 for further information.

3 Daily average of at least four determinations.

indiscernible because of the overriding influence of variations in turbidity on well clogging.

The Bay Park recharge system permitted little air entrainment because the water was injected under pressure well below static level. Also, because the temperature of the reclaimed water was about equal to or warmer than the temperature of the aquifer water in all tests, any gases dissolved in the injected water would tend to remain in solution within the higher pressure and lower temperature environment of the aquifer.

\section{BIOLOGICAL CLOGGING}

The reclaimed water that was injected was ordinarily chlorinated as the final step in the tertiarytreatment process. A chlorine dosing of 5 to $7 \mathrm{mg} / \mathrm{L}$ provided an effective bacterial kill. With this dosage and approximately 2 hours of contact time, the residual chlorine level of the water at the point of injection was approximately $2 \mathrm{mg} / \mathrm{L}$. Under these conditions, microbial growth around the screen of the recharge well was effectively suppressed, and 


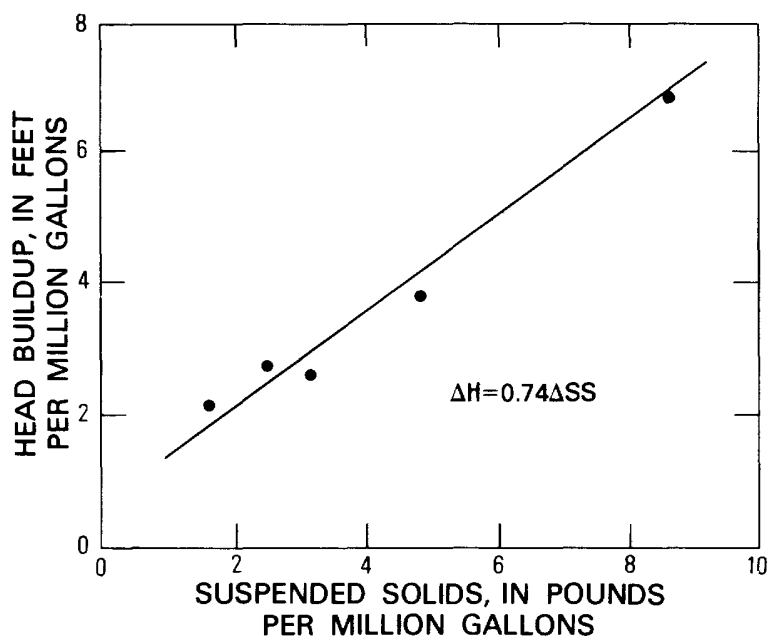

FIGURE 9.-Relationship between suspended solids in injected water and rate of head buildup in injection well. (From Vecchioli and others, 1975, p. 208.)

clogging caused by microbial factors was insignificant (Ehrlich and others, written commun., 1977).

Considerable microbial clogging did take place, however, in test RW8, in which unchlorinated water was injected (Ehrlich and others, 1973). Although turbidity of the injectant in this test was very low, the rate of clogging was higher than in other tests in which chlorinated water having higher turbidity was injected. (See table 6.) Moreover, in this test, much of the clogging took place within the gravel pack of the injection well, in contrast with the clogging observed in other tests, which was mostly at the interface between the gravel pack and the aquifer. Near the end of test RW8, the head in the injection well was about 12 feet higher than in the observation well within the gravel pack, whereas in all other tests, the difference in head was on the order of 0.1 foot. Bacterial analyses of water recovered from the filter pack and of material in a sandfilled probe suspended in the observation well tapping the filter pack during the test indicate that microbial growth and associated slimes caused much of the observed loss in specific capacity of the recharge well (Ehrlich and others, 1973, p. 344).

\section{CHEMICAL CLOGGING}

Compounds of iron, aluminum, and phosphorous accumulated in the vicinity of the injection well and contributed to clogging in most of the tests. Part of the accumulation resulted from the filtration of the colloidal or larger particulate form of these constituents from the injected water. However, part of the accumulation may have resulted from the chem- ical precipitation of the dissolved fraction of these constituents at or near the aquifer face. According to Ragone (1977), application of WATEQ, the computer program of Truesdall and Jones (1974), to the chemical data showed that the water recovered early during pumping of the injection well was supersaturated with aluminum and iron hydroxy species and iron oxide species. Hence, some chemical precipitation of some or all of these species could have occurred in some of the tests.

It was not possible to demonstrate that purely chemical clogging occurred in any test because of the overwhelming influence of mechanical clogging and because the chemical species involved also made up part of the particulate load injected. For example, Ragone and others (1973) found that the amount of iron recovered from the recharge well during repumping after test RW10 was equal to the amount of colloidal iron in the reclaimed water injected. In any event, some of the material that caused clogging of the recharge well could not be removed by pumping and surging alone, as one might expect if the clogging were purely mechanical. Dosing the well with hydrochloric acid after test RW7 led to recovery of water high in aluminum, iron, and phosphorus (table 7) and to a nearly 50percent improvement in specific capacity (Vecchioli, 1972 , p. 95). A second acid treatment applied at the end of test RW13 resulted in a 25-percent improvement in specific capacity. These redevelopment episodes are described more fully in a following section.

\section{FLOWMETER SURVEYS}

Attempts were made at using flowmeter surveys to identify those zones in the screened interval of the injection well that became clogged most readily during recharge. These surveys were made with a

TABLE 7.-Aluminum, iron, and phosphate concentrations and $p H$ of liquid pumped after acid treatment of injection well after test $R W^{\prime}$

[All chemical concentrations are in milligrams per liter. From Vecchioli, 1972 , p. 95$]$

\begin{tabular}{ccccc}
\hline $\begin{array}{c}\text { Total gallons } \\
\text { pumped at time } \\
\text { of sample } \\
\text { collection } \\
\text { (thousands) }\end{array}$ & $\begin{array}{c}\text { Total } \\
\text { aluminum } \\
\text { (Al) }\end{array}$ & $\begin{array}{c}\text { Total } \\
\text { iron } \\
\text { (Fe) }\end{array}$ & $\begin{array}{c}\text { Total } \\
\text { phosphorus } \\
\text { as PO) }\end{array}$ & $\mathrm{pH}$ \\
\hline${ }^{1}$ ) & 5 & 0 & 0.1 & $-\overline{30}$ \\
8 & 94 & 44 & 61 & 0.65 \\
16 & 28 & 15 & 13 & .70 \\
24 & 17 & 12 & 11 & .94 \\
32 & 16 & 10 & 8.2 & 1.00 \\
40 & 12 & 3.4 & 7.2 & 1.07 \\
48 & 10 & 8.3 & 6.0 & 1.42 \\
96 & 4 & 7.2 & 2.2 & 1.68 \\
144 & 2.6 & 1.9 & 1.6 & 1.93 \\
192 & 1.8 & 1.5 & .9 & \\
\hline
\end{tabular}

Analysis of acid. 
3-inch Au-type current meter suspended at different depths in the recharge well. Flowmeter surveys made during pumping and before injection indicated that the zone between 440 and 450 feet below land surface was the interval of highest yield (Vecchioli and others, 1974, p. 17). The surveys also indicated that roughly 60 percent of the yield was contributed through the lower half of the screen. (See figure 10.)

In contrast, roughly 60 percent of the flow was transmitted through the upper half of the screen during injection. This difference was first recognized

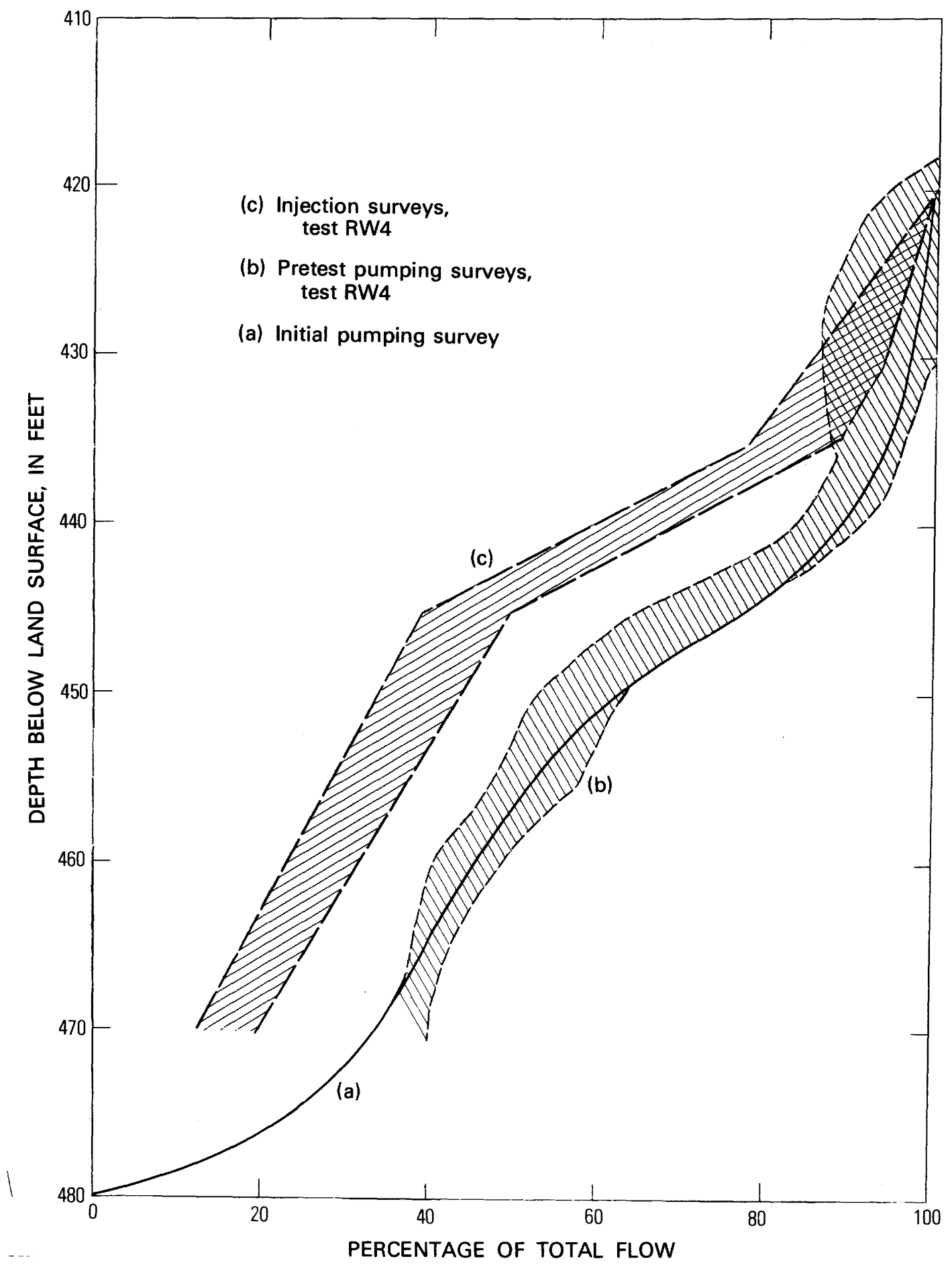

Figure 10.-Depth distribution of flow through well screen during (a) initial flowmeter survey before any injection, (b) pumping before test RW4, and (c) injection in test RW4. 
by G. D. Bennett (written commun., 1969) during the early series of recharge experiments made with public-supply water. In all injection tests in which flowmeter surveys were made, results differed distinctly from those of the pumping surveys, regardless of the degree to which the injection well was clogged. For example, in figure 10, the band of injection surveys represents the spread of five individual surveys made at widely spaced time intervals during test RW4. The first flowmeter survey was run within 3 hours of the start of injection, when little or no clogging had developed; the last survey was run after 10 days of injection, by which time the specific capacity of the well had decreased by more than 40 percent. No time-related trend was apparent among the five flowmeter surveys, which suggests that the spread represents variations in measurement procedure rather than any correlation with the degree of well clogging. Similar results were obtained in several other tests.

The direction of flow apparently controls the relative contribution or acceptance of water at the different depth intervals in the screened zone. A possible explanation may be that the 3 -inch-diameter current meter that presumably was centered in the 16-inch-diameter well screen may not have been sensing the same proportion of flow through the cross section for both directions of flow. The difference between the injection-survey results and the pumping-survey results is not great (fig. 10).

Another explanation may be related to the slight vertical gradient in the aquifer when the well is not being operated. The head in the aquifer opposite the top of the screen is less than the head in the aquifer opposite the bottom of the screen. The actual difference is not known but is probably less than a tenth of a foot. Therefore, when the head in the well is drawn down during pumping, a slightly greater gradient toward the well is formed in the lower half of the screen than in the upper half. During injection, when the head in the well is raised, the reverse is true; that is, the gradient away from the well is steeper in the upper half of the screen than in the lower half. Although these differences in gradient are slight, they could account at least in part for the slight differences in the configuration of the flowmeter surveys.

In summary, the flowmeter surveys were not useful in determining whether any zones clogged preferentially. The difference between results of surveys made during pumping and those made during injection was at least as great as the differences within either group.

\section{REDEVELOPMENT OF REGHARGE WELL}

\author{
PUMPING AND SURGING
}

After each injection test, the injection well was redeveloped by pumping and surging at different rates up to $1,000 \mathrm{gal} / \mathrm{min}$. In general, this restored specific capacity only partly. For example, after the specific capacity of the well was reduced from 30.3 to $17.7(\mathrm{gal} / \mathrm{min}) / \mathrm{ft}$ after 10 days of injection in test RW4, redevelopment of the well was attempted by continuous pumping at varying rates $(400,500$, and $900 \mathrm{gal} / \mathrm{min}$ ) for 5 days. After the first hour of pumping, specific capacity improved to about 26 (gal/min) $/ \mathrm{ft}$ but increased to only 28.5 (gal/ $\mathrm{min}$ )/ft after 5 days. The well was then surged 10 times by pumping at $1,000 \mathrm{gal} / \mathrm{min}$, the maximum capacity of the equipment, for 10-minute intervals followed by 5 -minute shutdown periods. No improvement in specific capacity was noted. This procedure was repeated after 2 days of continuous pumping; this time 20 surge-and-rest cycles were applied, but without causing noticeable improvement. Another 10 surge-and-rest cycles were applied 2 days later, again with no apparent success.

The longest period of injection uninterrupted by redevelopment was 33 days (test RW7), in which about $14 \mathrm{Mgal}$ of reclaimed water was injected. Rate of injection during this test was $350 \mathrm{gal} / \mathrm{min}$ during the first 19 days and $200 \mathrm{gal} / \mathrm{min}$ during the last 14 days. The rate decrease was brought about by a mechanical failure of one of the filters at the treatment plant. During this test, the specific capacity of the injection well decreased from a pretest value of $23.5(\mathrm{gal} / \mathrm{min}) / \mathrm{ft}$ to an end-of-test value of $\mathbf{2 . 5}$ $(\mathrm{gal} / \mathrm{min}) / \mathrm{ft}$. The major cause of clogging in this test was attributed to the suspended-solids load of the injected water (Ehrlich and others, 1972).

Redevelopment by pumping began 2 days after injection ended. Pumping at a steady rate of 300 $\mathrm{gal} / \mathrm{min}$ resulted in improvement of specific capacity, as follows :
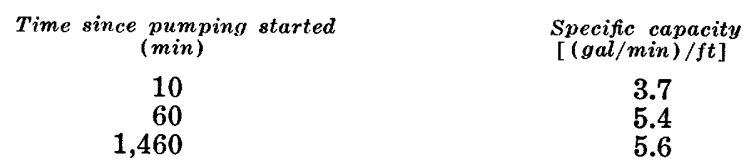

After pumping for 1 day, the well was shut down for 3 hours and then restarted and pumped for 1 hour at $700 \mathrm{gal} / \mathrm{min}$. At this rate, the specific capacity improved to 8.1 (gal/min) $/ \mathrm{ft}$ after 10 minutes and to $9.3(\mathrm{gal} / \mathrm{min}) / \mathrm{ft}$ after 60 minutes. Pumping was then halted for 3 weeks to observe potential changes in both the chemistry and microbiota of the injected water. 
Pumping was then resumed at $850 \mathrm{gal} / \mathrm{min}$, and a specific capacity of $15(\mathrm{gal} / \mathrm{min}) / \mathrm{ft}$ was observed after 4 hours of pumping. Continued pumping for an additional 20 hours at $500 \mathrm{gal} / \mathrm{min}$ resulted in no further improvement, and an abrupt increase to 900 $\mathrm{gal} / \mathrm{min}$ resulted in only a slight improvement, to $15.5(\mathrm{gal} / \mathrm{min}) / \mathrm{ft}$. The well was then surged 20 times by pumping at $1,000 \mathrm{gal} / \mathrm{min}$ for 10 -minute cycles, with 2-minute shutdown periods. After pumping overnight at $400 \mathrm{gal} / \mathrm{min}$, the specific capacity was observed to be $17.8 \mathrm{gal} / \mathrm{min}$. The same pattern of surging was repeated on the following 2 days, with only insignificant improvement in specific capacity to $18(\mathrm{gal} / \mathrm{min}) / \mathrm{ft}$.

The well head was then dismantled for repair of an epoxy joint. Because the pump had to be removed to make the repair and because increased surging due to stepped increases in pumping rate had resulted in substantial improvements to the well's specfic capacity, increased agitation within each increment of screen was attempted with a double surge-block air-pumping technique. The surge-block assembly consisted of two sets of flexible washers, which fit snugly in the screen, separated by a 2-foot length of slotted pipe. The 2-foot section of pipe served as the intake for water pumped out of the well by means of air-lift pumping. The double surge block was worked in a swabbing motion up and down the length of the screen in increments of 5 to 10 feet while water was being pumped from the well at $200 \mathrm{gal} / \mathrm{min}$. Presumably the agitation caused by the swabbing and pumping was largely confined to the 2 feet of well screen opposite the 2-foot interval between the surge blocks. At any given interval, the water pumped at first was typically extremely turbid, but became less so as the swabbing continued. Much particulate matter, some of it fine-grained aquifer material, was removed during this operation. Analysis of a water sample collected early in a swabbing run showed it to contain $1,820 \mathrm{mg} / \mathrm{L}$ total suspended solids, of which $248 \mathrm{mg} / \mathrm{L}$ were volatile. However, upon reinstallation of the pumping equipment, testing showed little improvement in specific capacity.

One possible reason for the lack of success in improving the specific capacity was that the agitation generated by the surge-block swabbing was no greater than that generated by starting the turbine pump. The turbidity of the water pumped during swabbing indicates that the agitation during swabbing exceeded that during pumping; however, if the increased agitation were confined largely to the filter pack of the well and not transmitted to the aquifer interface, then the particulate matter removed during the swabbing came primarily from the filter pack. This is quite possible because the 10-inchthick filter pack could have dissipated more energy vertically than laterally within the interval opposite the surge blocks. Hence, if the filter pack had been cleaned sufficiently by the preswabbing pumping, so as not to contribute significant head losses, further cleaning of the filter pack would result in no improvement of the well's specific capacity. In other words, the well's specific capacity at this point was being controlled primarily by reduction of permeability at the aquifer interface and a short distance beyond it, and this zone was apparently not affected by the swabbing any more than it had been earlier by simple pumping.

Effectiveness of pumping and surging in restoring specific capacity lost during each segment of test RW13 is summarized in table 8. During this test, except for an aborted start, injection was terminated, and the well was redeveloped by pumping whenever the specific capacity of the well decreased to 6 to 7 $(\mathrm{gal} / \mathrm{min}) / \mathrm{ft}$. The well was redeveloped seven times, and the specific capacity was increased to 12 to 13 $(\mathrm{gal} / \mathrm{min}) / \mathrm{ft}$. The amount of water pumped for redevelopment totaled about four percent of the amount injected.

\section{ACID TREATMENT}

In early tests, it was found that the water repumped from the injection well initially had high concentrations of iron and phosphate, mostly in particulate form (Vecchioli and $\mathrm{Ku}, 1972, \mathrm{p} .10$ ). In test RW7, high concentrations of aluminum were noted also. After the redevelopment attempts by pumping and surging after test RW7, it was thought by the authors that chemical deposits might be so firmly attached to the mineral framework of the aquifer that they could not be loosened by the surging action of the repumped water. The mode of formation of these deposits was not determined; that is, it is not known whether the deposits resulted from purely physical filtration of particulate matter or whether they resulted from coprecipitation of iron, aluminum, and phosphate at the interface or whether the process was a combination of the two. In any event, the residual deterioration in well capacity was thought by the authors to result largely from persistence of these compounds at the aquifer interface. Because many compounds of iron and aluminum are soluble in hydrochloric acid, the well was dosed with acid in an attempt to dissolve or at least dislodge these compounds. 
TABLE 8.-Redevelopment data, test RW13, October 24, 1972, to May 11, 1973

[From Sulam, 1973]

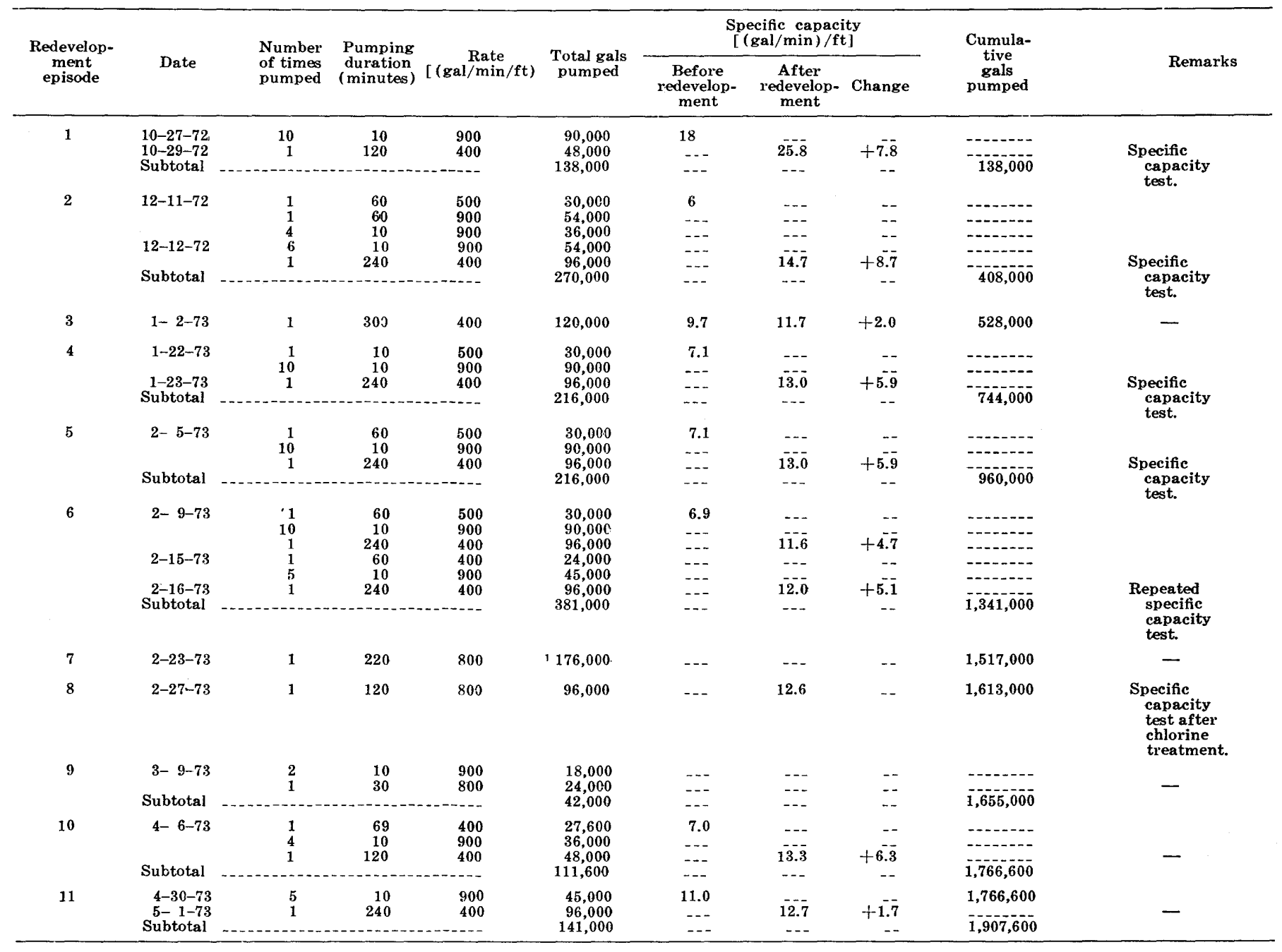

${ }^{1}$ After sodium hypochlorite solution was injected.

A 2,400-gallon slug of 32-percent commercialgrade hydrochloric acid was injected into the well by way of the annular-space observation well. This volume was determined to be sufficient to displace all water within the screened zone of the injection well and the annular-space well, as well as the water within the filter pack and within the first few inches of formation.

After the acid was injected, the turbine pump was turned on momentarily a few times to surge the well and thus assure even distribution of the acid around the well. The acid was then left standing in and around the well screen overnight (more than 12 hours). The following day, the pump was turned on, and the well was pumped continuously at $800 \mathrm{gal} / \mathrm{min}$. An immediate improvement in specific capacity was noted. After 4 hours of pumping, the specific capacity was 26.5 (gal/min) $/ \mathrm{ft}$-an im- provement of almost 50 percent over what it had been before the acid treatment and a 12-percent improvement over what it had been before test RW7. High concentrations of iron, aluminum, and phosphorus were noted in the liquid pumped from the well, as discussed in a previous section "Chemical Clogging."

The well was similarly treated with acid at the end of test RW13, and specific capacity improved from 20 to 25 (gal $/ \mathrm{min}) / \mathrm{ft}$.

\section{BACTERICIDE TREATMENT}

In test RW8, about $5 \mathrm{Mgal}$ of unchlorinated reclaimed water was injected at $340 \mathrm{gal} / \mathrm{min}$. During this test, the specific capacity of the injection well dropped from a pretest value of 26.5 to 11 (gal/ min)/ft. Most of the clogging in this test was attributed to a buildup of microbial slime within the 
filter pack and perhaps a short distance into the formation (Ehrlich and others, 1973). A head difference of about 12 feet between the injection well and the annular-space well was noted toward the end of the test; this reflects the slime buildup within the filter pack.

Redevelopment by pumping at rates up to 1,000 $\mathrm{gal} / \mathrm{min}$ was effective in restoring the specific capacity to only about $23(\mathrm{gal} / \mathrm{min}) / \mathrm{ft}$. The pumping also resulted in a removal of all but about 0.5 foot of head difference between the injection well and annular-space well when pumping at about $400 \mathrm{gal} /$ min. Before this last injection test, this head difference had been only 0.1 foot at a pumping rate of $400 \mathrm{gal} / \mathrm{min}$. As most of the residual clogging was thought by the authors to be of bacterial origin, shock chlorination was considered a reasonable remedial measure.

Chlorine was added to the well by injecting 33,000 gallons of aquifer water into which a 15-percent solution of sodium hypochlorite was mixed; this resulted in a total chlorine residual of $200 \mathrm{mg} / \mathrm{L}$. This volume was sufficient to displace all water within the well casing below the point of injection, the screened interval, the filter pack, and the formation to a radial distance of almost 8 feet from the axis of the well. The chlorine solution was left standing overnight (more than 8 hours). The following day, after 4 hours pumping, the specific capacity was 26.5 (gal/ $\min$ ) /ft, which was equal to the specific capacity before injection of the unchlorinated reclaimed water. Also, the abnormal head difference between the annular-space well and the injection well had disappeared. Hence, the chlorine dosing was effective in destroying the residual bacterial slime around the injection well.

The well was similarly treated with chlorine after test RW9. Postinjection redevelopment by pumping had restored specific capacity to $24.6(\mathrm{gal} / \mathrm{min}) / \mathrm{ft}$. After the chlorine treatment, the specific capacity was improved to $27.1(\mathrm{gal} / \mathrm{min}) / \mathrm{ft}$.

The well was treated a third time with chlorine after segment 12 of test RW13. However, this treatment produced no significant improvement in specific capacity.

The recharge well was dosed with a commercial ammonium compound designed to control the growth of nuisance organisms in wells after test RW4 and after considerable redevelopment by pumping and surging. This treatment resulted in a 7-percent improvement in specific capacity (Vecchioli and $\mathrm{Ku}$, 1972, p. 10). A later treatment did not produce any improvement, however.

\section{RESTING}

Some improvement in specific capacity resulted from biodegradation of the clogging materials during periods after injection in which the well was rested for several weeks. Evidence for this phenomenon was observed after tests RW7, RW10, and RW13.

In test RW7, an increase in pumping rate from $700 \mathrm{gal} / \mathrm{min}$ to $850 \mathrm{gal} / \mathrm{min}$ after 3 weeks of rest was accompanied by a more than 60-percent improvement in specific capacity. This increase is probably more than would have occurred had the pumping rate been increased before any resting period.

After test RW10, the injection well was pumped at $300 \mathrm{gal} / \mathrm{min}$ for 110 minutes immediately after injection ended. The specific capacity was about $20(\mathrm{gal} / \mathrm{min}) / \mathrm{ft}$. The well was then rested for 35 days, after which it was again pumped at $300 \mathrm{gal} /$ min for about 60 minutes. Specific capacity then was $25.9(\mathrm{gal} / \mathrm{min}) / \mathrm{ft}$. High bacterial counts, high dissolved sulfide concentrations, and high total organic carbon concentrations in the recovered water suggest that bacteria were solubilizing the organic part of the clogging materials during the resting period (Ehrlich and others, 1979).

Similarly, at the end of test RW13, the specific capacity of the well was $8.6(\mathrm{gal} / \mathrm{min}) / \mathrm{ft}$. The well was rested for almost 1 month before redevelopment began. Highly turbid, odiferous water similar to that observed in test RW10 was pumped initially. Pumping and surging after the 1-month test restored the specific capacity to between 19 and 20 $(\mathrm{gal} / \mathrm{min}) / \mathrm{ft}$, whereas similar redevelopment attempts immediately or within a few days after different segments of injection resulted in specificcapacity improvement to only 12 or 13 (gal/ $\min ) / \mathrm{ft}$.

\section{SUMMARY}

Public-supply water and water reclaimed through tertiary treatment of sewage were injected into the Magothy aquifer at Bay Park, N.Y., in a series of 19 artificial-recharge experiments from 1968 to 1973. Injection was done through a well screened from 418 to 480 feet below land surface. Injection rates ranged from 185 to $400 \mathrm{gal} / \mathrm{min}$, and tests ranged from 2 to 33 days in length, except for the last experiment, in which almost $42 \mathrm{Mgal}$ of reclaimed water were injected intermittently in 18 segments over a 6-month period. Selected treatments were applied to the injectant in some tests to evaluate their effect on well clogging or on geochemi- 
cal reactions within the aquifer. The water injected was repumped after each test.

Head buildup in the aquifer during injection virtually mirrored drawdown during pumping of comparable magnitude and time. However, the injection well and (or) contiguous part of the aquifer became clogged to varying degrees in each test and resulted in excessive head buildup in the injection well. The amount of excessive head buildup and corresponding decrease in specific capacity differed widely from test to test. Maximum reduction in specific capacity, from 23.5 to $2.5(\mathrm{gal} / \mathrm{min}) / \mathrm{ft}$, was during injection of $14 \mathrm{Mgal}$ of reclaimed water.

Clogging of the well was due primarily to suspended solids in the injectant. Suspended-solids concentrations abiove $1 \mathrm{mg} / \mathrm{L}$, as $\mathrm{SiO}_{2}$, measured in terms of turbidity, caused disproportionately higher rates of clogging than concentrations below $1 \mathrm{mg} / \mathrm{L}$. Clogging due to microbial growth was insignificant as long as a total residual chlorine level of about 2 $\mathrm{mg} / \mathrm{L}$ was maintained in the injectant. However, in a 10-day test in which unchlorinated reclaimed water was injected, clogging due mainly to microbial factors was more severe than in comparable tests in which water of higher turbidity was injected. Compounds of iron, aluminum, and phosphorous contributed to clogging, but the extent to which these compounds precipitated within the aquifer relative to the particulate content of the injectant remained unresolved.

Redevelopment of the recharge well by pumping and surging was effective in partly restoring the specific capacity lost during an injection test. Maximum pumping rate was limited by the equipment to $1,000 \mathrm{gal} / \mathrm{min}$. Dosing the well with hydrochloric acid helped remove clogging material that could not be dislodged by pumping alone. Specific capacity improved from 18 to 26.5 ( $\mathrm{gal} / \mathrm{min}$ ) $/ \mathrm{ft}$ after the first acid treatment and from 20 to 25 (gal $/ \mathrm{min}) / \mathrm{ft}$ after a second treatment. Dosing of the well with solutions of sodium hypochlorite resulted in a 10- and 15-percent improvement in specific capacity on two occasions, but produced no significant improvement on a third. Dosing with an ammonium compound bactericide resulted in a 7-percent improvement in specific capacity, but a later, similar application produced no improvement. Redevelopment by pumping and surging was enhanced if the injection well was rested for several weeks after injection; this was because of biodegradation of the clogging materials during the rest periods.

\section{REFERENCES CITED}

American Water Works Association, Task Group 2440-R on Artificial Ground-Water Recharge, 1965, Experience with injection wells for artificial ground-water recharge: American Water Works Association Journal, v. 57, no. 5, p. $629-639$.

Cohen, Philip, and Durfor, C. N.,1967, Artificial-recharge experiments utilizing renovated sewage-plant effluent-a feasibility study at Bay Park, New York, U.S.A.: International Association of Scientific Hydrology Publication 72, p. 194-199.

Cohen, Philip, Franke, O. L., and Foxworthy, B. L., 1968, An atlas of Long Island's water resources: New York Water Resources Commission Bulletin 62, 117 p.

Cohen, Philip, and Kimmel, G. E., 1970, Status of salt-water encroachment in 1969 in southern Nassau and southeastern Queens, Long Island, New York, in Geological Survey Research 1970: U.S. Geological Survey Professional Paper 700-D, p. D281-D286.

Ehrlich, G. G., 1972, Role of biota in underground waste injection and storage, in Cook, T. J., ed., Underground Waste Management and Environmental Implications: American Association of Petroleum Geologists Memoir 18, p. 298-307.

Ehrlich, G. G., Ehlke, T. A., and Vecchioli, John, 1972, Microbiological aspects of ground-water recharge-injection of purified chlorinated sewage effluent, in Geological Survey Research 1972: U.S. Geological Survey Professional Paper 800-B, p. B241-B245.

Ehrlich, G. G., Ehlke, T. A., and Vecchioli, John, 1973, Microbiological aspects of ground-water recharge-injection of purified unchlorinated sewage effluent at Bay Park, Long Island, New York: U.S. Geological Survey Journal of Research, v. 1, no. 3, p. 341-344.

Ehrlich, G. G., Ku, H. F. H., Vecchioli, John, and Ehlke, T. A., 1979, Microbiological effects of recharging the Magothy aquifer at Bay Park, New York, with tertiarytreated sewage: U.S. Geological Survey Professional Paper 751-E, 18 p.

Faust, S. D., and Vecchioli, John, 1974, Injecting highly treated sewage into a deep sand aquifer: American Water Works Association Journal, v. 66, no. 6, p. 371-377.

Franke, O. L., 1968, Double-mass-curve analysis of the effects of sewering on ground-water levels on Long Island, New York, in Geological Survey Research 1968: U.S. Geological Survey Professional Paper 600-B, p. B205-B209.

Garber, M. S., and Sulam, D. J., 1976, Factors affecting declining water levels in a sewered area of Nassau County, New York: U.S. Geological Survey Journal of Research, v. 4, no. 3, p. 255-265.

Koch, Ellis, Giaimo, A. A., and Sulam, D. J., 1973, Design and operation of the artificial-recharge plant at Bay Park, New York: U.S. Geological Survey Professional Paper 751-B, $14 \mathrm{p}$.

Ku, H. F. H., Vecchioli, John, and Ragone, S. E., 1975, Changes in concentration of certain constituents of treated waste water during movement through the Magothy aquifer, Bay Park, New York: U.S. Geological Survey Journal of Research v. 3, no. 1, p. 89-92.

Lusczynski, N. J., and Swarzenski, W. V., 1966, Salt-water encroachment in southern Nassau and southeastern Queens Counties, Long Island, New York: U.S. Geological Survey Water-Supply Paper 1613-F, 76 p. 
Perlmutter, N. M., and Geraghty, J. J., 1963, Geology and ground-water conditions in southern Nassau and southeastern Queens Counties, Long Island, New York: U.S. Geological Survey Water-Supply Paper 1613-A, 205 p.

Perlmutter, N. M., Pearson, F. J., Jr., and Bennett, G. D., 1968, Deep-well injection of treated waste-water-an experiment in re-use of ground water in western Long Island, in New York State Geological Association Guidebook 40th Ann. Mtg: p. 221-231.

Peters, J. H., 1968, Supplemental water supply by tertiary treatment and recharge, in Proceedings of the Fourth American Water Resources Conference: American Water Resources Association Proceedings Series, no. 6, p. 330343.

Peters, J. H., and Rose, J. L., 1968, Water conservation by reclamation and recharge: American Society of Civil Engineers Proceedings, Journal of Sanitary Engineering Division, v. 94, No. SA4, p. 625-639.

Ragone, S. E., 1977, Geochemical effects of recharging the Magothy aquifer, Bay Park, New York, with tertiarytreated sewage: U.S. Geological Survey Professional Paper 751-D, 22 p.

Ragone, S. E., Vecchioli, John, and Ku, H. F. H., 1973, Shortterm effect of injection of tertiary-treated sewage on iron concentration of water in Magothy aquifer, Bay Park, New York: American Association of Petroleum Geologists, Second International Symposium on Underground Waste Management and Artificial Recharge, v. 1, p. 273290.

Ragone, S. E., and Vecchioli, John, 1975, Chemical interaction during deep-well recharge, Bay Park, New York: Ground Water, v. 13 , no. 1, p. 17-24.

Ragone, S. E., Ku, H. F. H., and Vecchioli, John, 1975, Mobilization of iron in water in the Magothy aquifer during long-term recharge with tertiary-treated sewage, Bay Park, New York: U.S. Geological Survey Journal of Research, v. 3 , no. 1 , p. 93-98.

Sulam, D. J., 1973, Summary log of injection test RW13, Bay Park, N.Y.: U.S. Geological Survey open-file report, 23 p.
Temporary [New York] State Commission of Water Supply Needs of Southeastern New York, 1972, Scope of public water supply needs: Albany, New York, p. 142-144.

Truesdall, A. H., and Jones, B. F., 1974, WATEQ, a computer program for calculating chemical equilibria in natural waters: U.S. Geological Survey Journal of Research, v. 2, no. 2, p. 233-248.

Vecchioli, John, 1970, A note on bacterial growth around a recharge well at Bay Park, Long Island, New York: Water Resources Research, v. 6, no. 5, p. 1415-1419. 1972, Experimental injection of tertiary-treated sewage in a deep well at Bay Park, Long Island, New York-a summary of early results: New England Water Works Association Journal, v. 86, no. 2, p. 87-103.

Vecchioli, John, Bennett, G. D., Pearson, F. J., Jr., and Cerrillo, L. A., 1974, Geohydrology of the artificial-recharge site at Bay Park, Long Island, New York: U.S. Geological Survey Professional Paper 751-C, 29 p.

Vecchioli, John, Ehrlich, G. G., and Ehlke, T. A., 1972, Travel of pollution-indicator bacteria through the Magothy aquifer, in Geological Survey Research 1972: U.S. Geological Survey Professional Paper 800-B, p. B237-B239.

Vecchioli, John, and Giaimo, A. A., 1972, Corrosion of wellcasing and screen metals in water from the Magothy aquifer and in injected reclaimed water, Bay Park, Long Island, New York, in Geological Survey Research 1972: U.S. Geological Survey Professional Paper 800-B, p. p. B247-B251.

Vecchioli, John, and Ku, H. F. H., 1972, Preliminary results of injecting highly treated sewage-plant effuent into a deep sand aquifer at Bay Park, New York: U.S. Geological Survey Professional Paper 751-A, 14 p.

Vecchioli, John, Oliva, J. A., Ragone, S. E., and Ku, H. F. H., 1975, Wastewater reclamation and recharge, Bay Park, New York: American Society of Civil Engineers, Journal of the Environmental Engineering Division, v. 101, no. EE2, Proceedings Paper 11232, p. 201-214. 



\section{Deep-Well Artificial-Recharge Experiments at Bay Park, Long Island, New York}

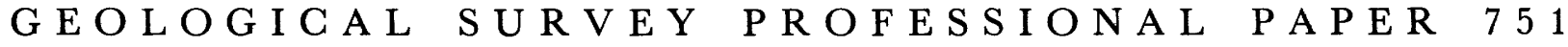

This volume was published

as separate chapters $A-F$

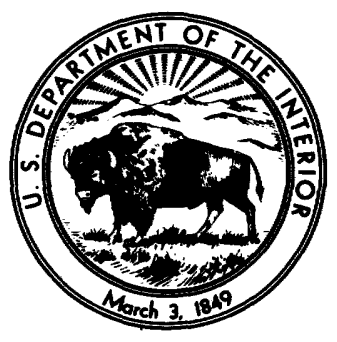




\section{UNITED STATES DEPARTMENT OF THE INTERIOR}

CECIL D. ANDRUS, Secretary

\section{GEOLOGICAL SURVEY}

H. William Menard, Director 


\section{CONTENTS}

\section{[Letters designate the chapters]}

(A) Preliminary results of injecting highly treated sewage-plant effluent into a deep sand aquifer at Bay Park, New York, by John Vecchioli and Henry F. H. Ku.

(B) Design and operation of the artificial-recharge plant at Bay Park, New York, by Ellis Koch, Anthony A. Giamo, and Dennis J. Sulam.

(C) Geohydrology of the artificial-recharge site at Bay Park, Long Island, New York, by John Vecchioli, G. D. Bennett, F. J. Pearson, Jr., and L. A. Cerrillo.

(D) Geochemical effects of recharging the Magothy aquifer, Bay Park, New York, with tertiarytreated sewage, by Stephen E. Ragone.

(E) Microbial effects of recharging the Magothy aquifer, Bay Park, New York, with tertiary-treated sewage, by Garry G. Ehrlich, Henry F. H. Ku, John Vecchioli, and Theodore A. Ehlke.

(F) Hydraulic effects of recharging the Magothy aquifer, Bay Park, New York, with tertiary-treated sewage, by John Vecchioli, Henry F. H. Ku, and Dennis J. Sulam. 

